\title{
OBRAZKOWY POMIAR CECH OSOBOWOŚCI DZIECI - PREZENTACJA METODY
}

MARTA ROGOZA *

Instytut Psychologii, Uniwersytet Kardynała Stefana Wyszyńskiego w Warszawie

\section{STRESZCZENIE}

Obecnie przyjmuje się, że strukturę osobowości, również w okresie dzieciństwa, można opisać za pomocą cech Wielkiej Piątki. Dużym problemem jest jednak taki sposób pomiaru, który uwzględniałby kształtujące się dopiero umiejętności czytania, koncentracji oraz inne aspekty rozwoju poznawczego badanych osób młodych. Celem niniejszego artykułu jest prezentacja Obrazkowego pomiaru cech osobowości dzieci (OPCO-D), czyli kwestionariusza do pomiaru 5 czynników osobowości, tj.: ekstrawersji, neurotyczności, otwartości, sumienności i ugodowości w okresie późnego dzieciństwa. Kwestionariusz OPCO-D można uznać za zadowalające, rzetelne i trafne uzupełnienie istniejącej narzędziowej luki w sposobach pomiaru cech osobowości u dzieci, zwłaszcza między 7. a 10. rokiem życia. Łączy w sobie zalety pomiaru zarówno kwestionariuszowego, jak i niekwestionariuszowego i jest dostosowany do rozwoju poznawczego oraz do możliwości dzieci.
27 CHARAKTERYSTYKA TEORETYCZNA MODELU WIELKIEJ PIĄTKI CECH OSOBOWOŚCI

28 POMIAR CECH WIELKIEJ PIĄTKI W OKRESIE DZIECINSSTWA

29 KONSTRUKCJA OBRAZKOWEGO POMIARU CECH OSOBOWOŚCI DZIECI (OPCO-D)

33 WŁAŚCIWOŚCI PSYCHOMETRYCZNE OPCO-D

39 PODSUMOWANIE

40 BIBLIOGRAFIA

42 ANEKS 


\title{
THE PICTORIAL PERSONALITY TRAITS QUESIONNAIRE - PRESENTATION OF THE QUESTIONNAIRE
}

\begin{abstract}
Currently, it is assumed that the personality structure, including the period of the childhood, could be described through the means of the Big Five traits. A big challenge, however, is to select such a measure, which would take into account the development of reading, concentration, and other cognitive aspects, which are still developing in younger children. Therefore, the aim of the current study if to demonstrate that the Pictorial Personality Traits Questionnaire for Children (PPTQ-C), which is a questionnaire designed to capture five basic personality traits, that is: extraversion, neuroticism, openness, conscientiousness, and agreeableness during the late childhood period. The PPTQ-C could be deemed as a valid and reliable tool, which covers the existing lack in such tools, especially for children aged between 7 and 10 years. The PPTQ-C combines the best features of questionnaire and non-questionnaire methods of assessment and is adjusted to the cognitive development of children.
\end{abstract}

\section{KEYWORDS}

personality traits, Big Five, childhood, PPTQ-C 


\section{CHARAKTERYSTYKA TEORETYCZNA MODELU WIELKIEJ PIĄTKI CECH OSOBOWOŚCI}

$\mathrm{M}$

odel Wielkiej Piątki jest obecnie dominującym modelem opisującym katalog oraz strukturę cech osobowości (McCrae, Costa, 1997). Najbardziej powszechną propozycją struktury cechowej osobowości w ujęciu kwestionariuszowym jest Pięcioczynnikowy Model Osobowwości (PMO; McCrae, Costa, 2005). McCrae i Costa (1997, 2005) proponują następującą taksonomię pięciu cech: neurotyczność, ekstrawersja, otwartość na doświadczenie, ugodowość i sumienność.

Neurotyczność to cecha osobowości, która odnosi się do przystosowania emocjonalnego związanego z podatnością na doświadczanie negatywnych emocji, np.: strachu, zmieszania, gniewu, poczucia winy. Obejmuje również niezdolność do kontrolowania własnych pragnień i popędów oraz skłonność do nadmiernego autokrytycyzmu. Należy podkreślić, że neurotyczność jako cecha może wskazywać na ryzyko wystąpienia zaburzeń zachowania, jednak wciąż pozostaje wyłącznie wymiarem osobowości niezaburzonej (McCrae, Costa, 1997). Ekstrawersja to cecha osobowości, która charakteryzuje jakość i ilość interakcji społecznych, co wiąże się z towarzyskością, łatwością nawiązywania kontaktów społecznych oraz poszukiwaniem stymulacji w tychże relacjach oraz innych obszarach. Cecha ta obejmuje również takie charakterystyki jak: poziom aktywności, energii i łatwość w odczuwaniu emocji pozytywnych. Otwartość na doświadczenie to cecha określająca tendencję do poszukiwania, pozytywnego wartościowania własnych doświadczeń życiowych oraz ciekawości poznawczej związanej z tolerancją nowości. Dotyczy ciekawości nowych idei, pomysłów, doświadczeń i przeżyć. To cecha, która najbardziej ze wszystkich pięciu charakterystyk związana jest $\mathrm{z}$ intelektem. Ugodowość odnosi się do nastawienia wobec innych ludzi, to interpersonalna orientacja, która ma odzwierciedlenie w uczuciach, myślach oraz działaniach. Przejawia się ona w tendencji do ufania ludziom, umiejętności wspólpracy, udzielania pomocy, a także w sposobie myślenia o innych. Ujawnia się w bezinteresownej trosce o inne osoby oraz w zaufaniu i hojności okazywanych ludziom. Ostatnia cecha osobowości wyszczególniona w PMO, czyli sumienność, odnosi się do stopnia zorganizowania człowieka, jego wytrwałości i sposobu motywacji w dążeniu do zamierzonego celu (Zawadzki, Strelau, Szczepaniak, Śliwińska, 1998). Cecha ta przejawia się głównie jako pracowitość, skrupulatność oraz rzetelność w odniesieniu do wykonywanego zadania.

Tradycyjne badania dotyczące struktury osobowości prowadzone w modelu Wielkiej Piątki dotyczyły głównie okresu dorosłości (Costa, McCrae, 1976; McCrae, 2002; McCrae, Terracciano, 78 współpracowników Personality Profiles of Cultures Project, 2005). W swoich pracach badacze koncentrowali się na opisie struktury osobowości człowieka dorosłego i starzejącego się, jak również na stałości i zmienności osobowości. Wyniki badań pozwalają na jasne stwierdzenie, że cechy osobowości osób dorosłych można przewidywać w czasie, ponieważ wykazują one względnie wysoką stabilność. Ponadto można uznać je za konstrukty uniwersalne, przejawiające się i postrzegane w podobny sposób w różnych kulturach (Chan i in., 2012; De Bolle i in., 2015; Hendriks i in., 2003; McCrae, 2001; McCrae, Costa, 2005; McCrae i in., 2005). Pomimo wysokiego stanu wiedzy w ciągu ostatnich dekad można zaobserwować wzrost liczby opracowań dotyczących struktury osobowości we wcześniejszych okresach rozwojowych: dorastania, a nawet dzieciństwa (przegląd badań w: Caspi, Roberts, Shiner, 2005; Shiner, Caspi, 2003). Jest to wiedza przydatna tym bardziej, że wyniki badań pokazują, iż stabilność struktury osobowości u dzieci może być większa niż 
przypuszczano (zwłaszcza po trzecim roku życia), a stabilność cech osiąga punkt szczytowy później, niż sądzono - jak pokazują metaanalizy - dopiero po 50. roku życia (Shiner, Caspi, 2003). Niemniej jednak prowadzenie badań nad strukturą osobowości w okresie dzieciństwa jest wyjątkowym wyzwaniem i wymaga uwzględnienia charakterystyki rozwojowej tego okresu, w szczególności poziomu rozwoju poznawczego. Dotychczas badania samoopisowe nad osobowością w okresie dzieciństwa dotyczyły dzieci albo w średnim okresie dzieciństwa (między czwartym a siódmym rokiem życia; Ablow, Measelle, 1993), albo dzieci od dziewiątego roku życia (Barbaranelli, Caprara, Rabasca, Pastorelli, 2003), co przypada na drugą połowę okresu późnego dzieciństwa (Kołodziejczyk, 2011). Powstała zatem luka przypadająca na pierwszą połowę okresu późnego dzieciństwa.

\section{POMIAR CECH WIELKIEJ PIĄTKI W OKRESIE DZIECIŃSTWA}

Wyniki prowadzonych dotychczas badań pozwalają domniemywać, że struktura osobowości dzieci oraz adolescentów jest wysoce podobna do struktury osobowości dorosłego człowieka. Badania prowadzono zarówno w podejściu kwestionariuszowym, jak i niekwestionariuszowym

Pomiary kwestionariuszowe. Mervielde i De Fruyt (1999) opracowali kwestionariusz Hierarchical Personality Inventory for Children (HiPIC) w oparciu o analizowane opisy osobowości dzieci w wieku 3-12 lat sporządzone przez ich rodziców w siedmiu krajach (Belgii, Chinach, Niemczech, Grecji, Holandii, Polsce i Stanach Zjednoczonych). Początkowo był on przeznaczony dla obserwatorów, jednak w kolejnych badaniach $\mathrm{z}$ sukcesem zastosowano go jako metodę samoopisową w grupie od 12. do 17. roku życia (De Fruyt, Mervielde, Hoekstra, Rolland, 2000). W toku analiz zidentyfikowano pięć podstawowych wymiarów struktury osobowości dzieci, korespondujących z cechami Wielkiej Piątki (Kohnstamm, Halverson, Mervielde, Avilla, 1998; Mervielde, Asendorpf, 2000). Kwestionariusz ten jest odpowiednio dostosowany do dzieci w stadium operacji formalnych, co jest zgodne $\mathrm{z}$ zaleceniami autorów (De Fruyt i in., 2000), jednakże jego wykorzystanie wśród młodszych dzieci może być problematyczne.

Barbaranelli i wspólpracownicy (2003) skonstruowali kwestionariusz do pomiaru cech osobowości w rozumieniu Wielkiej Piątki - Big Five Questionnaire for Children (BFQ-C), który pozwala na dokonanie pomiaru w grupie dzieci w wieku od 9 do 13 lat. Pozycje testowe kwestionariusza BFQ-C opracowano w oparciu o przymiotniki będące określeniami cech, które zostały uznane przez nauczycieli i rodziców za najbardziej przydatne w konstruowaniu opisu osobowości dzieci (Barbaranelli i in., 2003). Badania, w których był wykorzystywany kwestionariusz BFQ-C, potwierdzają, że w okresie późnego dzieciństwa oraz w okresie wczesnej adolescencji dane samoopisowe organizują się wokól struktury pięcioczynnikowej (np.: Barbaranelli i in., 2003; Cieciuch, 2010; del Barrio, Carrasco, Holgado, 2006; Muris, Meesters, Diederen, 2005).

Pomiary niekwestionariuszowe. Jak się okazuje, badanie pięcioczynnikowej struktury osobowości możliwe jest również w okresie średniego dzieciństwa, czyli u dzieci w wieku przedszkolnym (cztery-sześć lat; Ablow, Measelle, 1993). Measelle, John, Ablow, Cowan i Cowan (2005) wykorzystali strukturalizowany wywiad Berkeley Puppet Interview, który polega na stworzeniu sytuacji konwersacji dziecka $z$ dwojgiem rówieśników ( $w$ tym przypadku zabawkami/lalkami), przy czym każde $z$ nich opisuje siebie w sposób zupełnie odmienny od drugiego. Następnie do dziecka jest kierowana prośba o to, by określiło, do której $\mathrm{z}$ lalek jest podobne. Pytania są prosto sformułowane, dostosowane do poziomu językowego dziecka, co zwiększa jego poziom zaangażowania w konwersację z lalkami, a także 
prawdopodobieństwo uzyskania właściwej, trafnej odpowiedzi (Measelle, Ablow, Cowan, Cowan, 1998).

Wykorzystanie pomiarów niekwestionariuszowych pozwala na badanie dzieci do siódmego roku życia, przy zastosowaniu zaś pomiaru kwestionariuszowego - od dziewiątego roku życia (Barbaranelli i in., 2003; Measelle i in., 2005), co tworzy lukę pomiarową dla dzieci między siódmym a dziewiątym rokiem życia. $Z$ jednej strony wykorzystanie $B e r-$ keley Puppet Interview (Ablow, Measelle, 1993) w tym okresie może okazać się nietrafne ze względu na jego dziecinny charakter, z drugiej zaś - zastosowanie BFQ-C (Barbaranelli i in., 2003) może okazać się jeszcze zbyt trudne. Ponadto okres ten jest najczęściej powiązany z rozpoczynającą się nauką szkolną, która stawia przed dziećmi zupełnie nowe wymagania oraz stwarza nowe środowisko rówieśnicze, gdzie dzieci uczą się rozmaitych interakcji społecznych (Kołodziejczyk, 2011), co czyni pomiar cech osobowości w tym okresie szczególnie interesującym.

\section{KONSTRUKCJA OBRAZKOWEGO POMIARU CECH OSOBOWOŚCI DZIECI (OPCO-D)}

Według Piageta (1960) okres późnego dzieciństwa obejmuje stadium operacji konkretnych, co oznacza, że w tym czasie rozwojowym dzieci dokonują operacji umysłowych jedynie w oparciu o konkretne, rzeczywiste przedmioty i wydarzenia, a zatem wszelkie informacje hipotetyczne i abstrakcyjne mogą nie być w pełni poprawnie przetwarzane. Dzięki ukształtowanej umiejętności myślenia logicznego formuje się również umiejętność przewidywania i wyjaśnianie zdarzeń (Stefańska-Klar, 2005). Spostrzeganie świata przez dziecko przestaje mieć cechy egocentryzmu, co oznacza, że zaczyna ono być zdolne do zrozumienia, że inni ludzie mogą spostrzegać rzeczy inaczej niż ono samo, a to wydaje się kluczowe dla badania różnic indywidualnych. Wszystkie te zmiany są powiązane $z$ funkcjonowaniem układu nerwowego, a tym samym z działaniem procesów (Kielar-Turska, Białecka-Pikul, Skórska, 2006). Rozwój poznawczy dzieci w tym okresie z jednej strony umożliwia prowadzenie badań nad ich osobowością za pomocą metod samoopisowych, ponieważ dzieci posiadają umiejętność czytania, potrafią myśleć przyczynowo-skutkowo oraz operować na materiale konkretnym, jednak $\mathrm{z}$ drugiej strony stawia przed badaczem trudności $\mathrm{w}$ postaci braku rozumienia informacji hipotetycznych i abstrakcyjnych, trudności z długotrwałym utrzymaniem uwagi oraz tendencji do odwoływania się do wydarzeń z przeszłości.

Przegląd badań wskazuje, że pomiarami kwestionariuszowymi najczęściej wykorzystywanymi w okresie późnego dzieciństwa są: Hierarchical Personality Inventory for Children (HiPIC; Mervielde, De Fruyt, 1999) oraz Big Five Questionnaire for Children (Barbaranelli i in., 2003), jednak żaden z nich nie wydaje się narzędziem wystarczająco odpowiednim do badania dzieci u progu okresu późnego dzieciństwa właśnie ze względu na charakterystykę rozwoju poznawczego. $Z$ tego powodu stworzono opisywany w niniejszym artykule Obrazkowy pomiar cech osobowości dzieci (OPCO-D).

Kwestionariusz OPCO-D jest propozycją wyjścia poza ograniczenia istniejących tradycyjnych metod pomiaru cech Wielkiej Piątki, dostosowaną do badania dzieci od 6. do 10. roku życia. Niewątpliwą inspiracją w powstawaniu OPCO-D był obrazkowy pomiar wartości, czyli Picture Based Value Survey for Children (PBVS-C) autorstwa Döring, Blauensteiner, Aryus, Drögekamp i Bilsky'ego (2010) w polskiej adaptacji Cieciucha, Harasimczuk i Döring (2010). Pomiar PBVS-C to zestaw rysunków, na których zaprezentowane zostały kolejne wartości w ujęciu Schwarza (1992). Innowacyjność PBVS-C polega na tym, że wartości będące kategoriami abstrakcyjnymi zostały przedstawione na przykładzie konkretnych sytuacji, w których zachowanie głównego bohatera było prezentacją konkretnych 
wartości. Podobny cel został obrany podczas konstrukcji OPCO; dla każdej z cech osobowości były wówczas poszukiwane behawioralne wskaźniki, które można było zilustrować.

\section{ZAŁOŻENIA KONSTRUKCJI OPCO-D}

Podczas konstrukcji kwestionariusza OPCO-D (Maćkiewicz, Cieciuch, 2012) przyjęto następujące założenia:

(1) Wielka Piątka jest odpowiednią klasyfikacją cech osobowości w okresie późnego dzieciństwa. Dotychczasowe badania wskazują, że taksonomia pięciu cech jest użyteczna w odniesieniu do dzieci oraz dorastających (Caspi i in., 2005);

(2) W badaniach osobowości dzieci warto poszukiwać danych samoopisowych. Dane pochodzące z opisu innych osób (nauczycieli, rodziców czy rówieśników) są swego rodzaju wypadkową obserwowanego zachowania dzieci i systemu poznawczego dorosłych, których struktura osobowości w zakresie pięciu czynników osobowości jest ukształtowana i stabilna;

(3) Kod obrazkowy jest bardziej odpowiedni do badania dzieci niż kod słowny. Poszukiwanie danych samoopisowych u dzieci wymaga specjalnych metod uwzględniających ich rozwój poznawczy.

\section{GŁÓWNY BOHATER OPCO-D, CZYLI „OSOBA W SZALIKU W PASKI”}

Pierwszym etapem prac nad Obrazkowym pomiarem cech osobowości było wykreowanie głównego bohatera, który będzie występował na wszystkich ilustracjach, a którego zachowanie będzie behawioralnym wskaźnikiem danej cechy osobowości i z którym dziecko wypełniające kwestionariusz będzie mogło się utożsamić. Aby ułatwić przebieg badań grupowych, stworzono tylko jednego głównego bohatera (o wyglądzie, z którym mogli utożsamić się zarówno chłopcy, jak i dziewczynki). Rysunek 1 przedstawia wstępne propozycje wyglądu głównego bohatera, rozważane podczas prac nad narzędziem. Na głównego bohatera została wybrana postać pierwsza, która spośród innych przedstawionych wyróżniała się bujną fryzurą i szalikiem w paski. Wersja ostateczna tej postaci została przedstawiona na rysunku 2 .

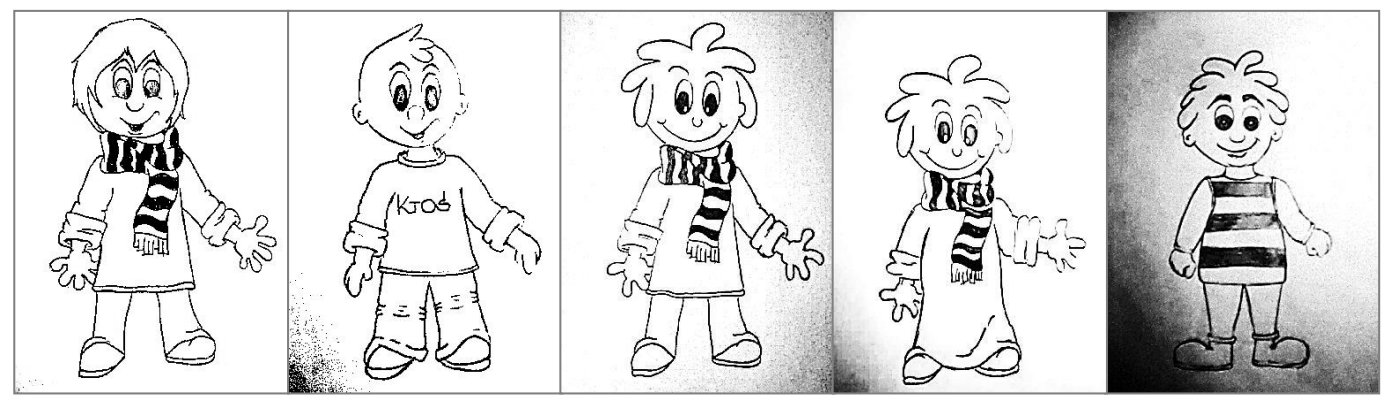

Rysunek 1. Projekty głównego bohatera Obrazkowego pomiaru cech osobowości. 


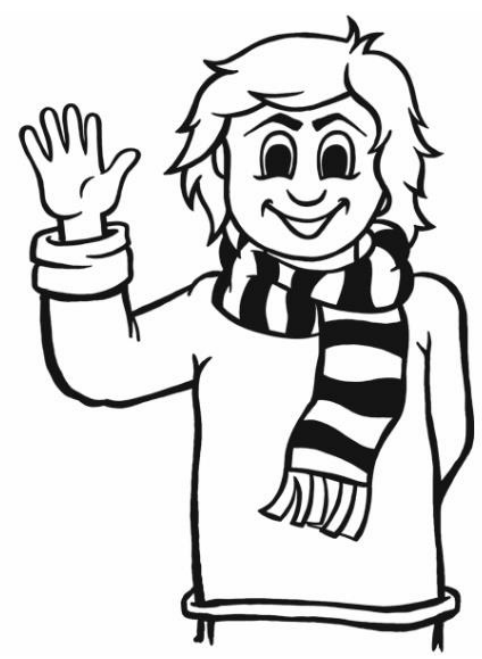

Rysunek 2. Główny bohater Obrazkowego pomiaru cech osobowości.

\section{INSTRUKCJA KWESTIONARIUSZA}

Na początku instrukcji kwestionariusza dziecku prezentowany jest główny bohater, obecny na każdym z obrazków na kolejnych stronach narzędzia. Zapowiedziane jest, że pokazywane będą pary obrazków, a na każdym z nich główny bohater będzie zachowywał się inaczej. Dziecko proszone jest, aby wybrało (przez zaznaczenie kwadracika przy wybranej ilustracji), czy częściej zachowuje się jak główny bohater na obrazku prawym czy na lewym. Jeśli zachowuje się czasem tak, a czasem tak, to może wybrać odpowiedź różnie, która znajduje się pomiędzy dwoma obrazkami. Zaznaczone jest również, że przy każdej pozycji można wybrać tylko jeden kwadrat.

\section{POZYCJE TESTOWE}

Na podstawie opisów cech osobowości w ujęciu Wielkiej Piątki w schemacie dedukcyjnym została stworzona początkowa baza pozycji testowych. Niezwykle istotna była kwestia, czy dane zachowanie można przedstawić w jednoznaczny sposób za pomocą obrazka. Następnie zilustrowane pozycje zostały poddane dyskusji oraz wstępnym badaniom. W ten sposób został ostatecznie wybrany zestaw 25 pozycji, czyli po pięć pozycji do każdej skali. W tabeli 1 przedstawiono treść wyróżnionych pozycji wchodzących w skład kwestionariusza OPCO-D. 
Tabela 1. Treść pozycji testowych wchodzących w skład ostatecznej wersji kwestionariusza OPCO-D

\begin{tabular}{|c|c|c|}
\hline Skala & Skrót & Pozycja testowa \\
\hline \multirow{5}{*}{ 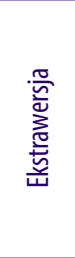 } & E1 & Zwykle bawię się: sam/sama vs z innymi \\
\hline & E2 & Z kolegami z klasy: dużo rozmawiam vs mało rozmawiam \\
\hline & E3 & Na przerwach wolę spędzaćc czas: sam/sama vs z kolegami/koleżankami z klasy \\
\hline & E4 & Kiedy inni bawią się: podchodzę do nich vs nie podchodzę do nich \\
\hline & E5 & Kiedy ktoś żartuje: nie śmieszy mnie to aż tak bardzo vs śmieję się razem z innymi \\
\hline \multirow{5}{*}{ 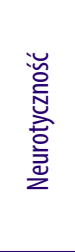 } & N1 & Kiedy coś mi nie wychodzi: szybko się denerwuję vs zachowuję spokój \\
\hline & N2 & Zwykle kiedy na coś czekam: czekam cierpliwie vs niecierpliwię się \\
\hline & N3 & Kiedy występuję przed innymi: denerwuję się vs raczej nie denerwuję się \\
\hline & N4 & Zwykle kiedy idę do szkoły: jestem spokojny/spokojna vs martwię się \\
\hline & N5 & Zazwyczaj: mam dobry humor vs mam zły humor* \\
\hline \multirow{5}{*}{ 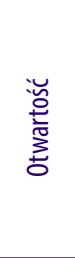 } & 01 & Kiedy widzę lecące ptaki: nie robi to na mnie wrażenia vs robi to na mnie duże wrażenie \\
\hline & 02 & Na wycieczce najbardziej lubię: odkrywać coś nowego vs bawić się i odpoczywać \\
\hline & 03 & W wolnym czasie: bawię się w ulubioną zabawę vs lubię dowiadywać się czegoś nowego \\
\hline & 04 & Nowe i ciekawe rzeczy: lubię poznawać vs nie lubię poznawać \\
\hline & 05 & Chętniej spędzam czas: w miejscach, które dobrze znam vs podróżując \\
\hline \multirow{5}{*}{ 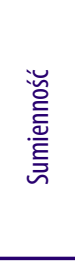 } & S1 & Domowe obowiązki wypełniam: chętnie vs niechętnie \\
\hline & S2 & W moim pokoju: jest bałagan vs jest porządek \\
\hline & S3 & Kiedy odrobię pracę domową: sprawdzam, czy nie ma gdzieś błędu vs od razu zaczynam się bawić \\
\hline & S4 & Kiedy istnieją jakieś zakazy: nie zwracam na nie uwagi vs stosuję się do nich \\
\hline & S5 & Kiedy dostanę od kogoś pieniądze: oszczędzam vs wydaję je od razu \\
\hline \multirow{5}{*}{$\begin{array}{l}\text { 容 } \\
\text { o } \\
\text { o } \\
\text { S }\end{array}$} & U1 & Kiedy ktoś z mojej klasy czegoś potrzebuje: nie zauważam tego vs zauważam to i mu pomagam \\
\hline & U2 & Kiedy widzę, że mogę komuś pomóc: pomagam vs nie pomagam \\
\hline & U3 & Kiedy mam nową rzecz: nie pożyczam jej innym vs pożyczam ją innym \\
\hline & U4 & Kiedy ktoś mnie za coś przeprasza: godzę się z nim szybko vs nie mam ochoty się z nim pogodzić \\
\hline & U5 & Kiedy coś zepsuję: nie przyznaję się do tego vs przyznaję się do tego \\
\hline
\end{tabular}

Każda z pozycji testowych składa się dwóch obrazków oraz skali, za pomocą której dziecko odpowiada na pytanie: „A jak zachowujesz się Ty?”. Odpowiedź udzielana jest na trzystopniowej skali, co jest dostosowane do rozwoju poznawczego dzieci (Borgers, de Leeuw, Hox, 2000; Hershey, Hill, 1976). Na rysunku 3 znajdują się dwa przykłady pozycji testowych OPCO-D. 


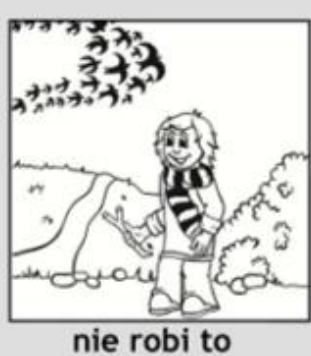

na mnie wrażenia

\section{Kiedy widzę lecące ptaki...} różnie
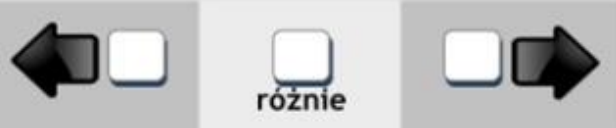

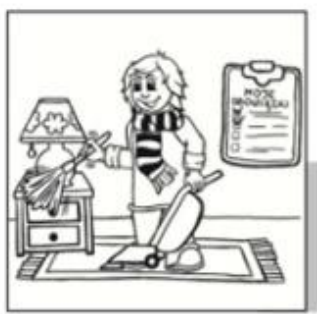

chętnie
4. Domowe obowiązki wypetniam...

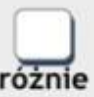
duże wrażenie
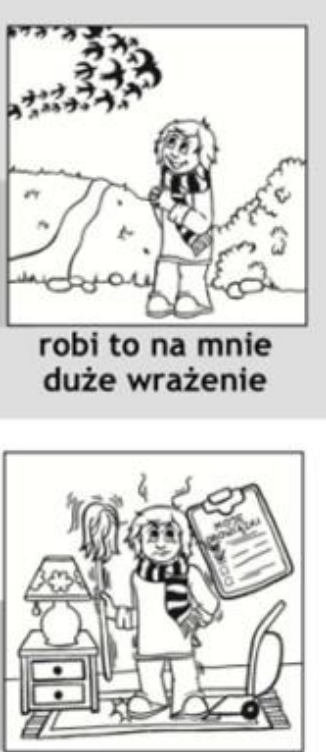

niechętnie

Rysunek 3. Budowa pozycji testowej.

Pozycje testowe stanowiące część właściwą kwestionariusza OPCO-D również składają się ze skali odpowiedzi oraz dwóch obrazków. Obrazki są tutaj wskaźnikami dwóch krańców danego wymiaru. Zachowanie głównego bohatera na jednym z obrazków jest wskaźnikiem niskiego natężenia cechy, podczas gdy na drugim obrazku główny bohater prezentuje zachowanie będące wskaźnikiem wysokiego natężenia danej cechy. Dzieci opisują siebie zazwyczaj w kategoriach teraźniejszości (Damon, Hart, 1982) - wiąże się to ze zdolnościami pamięciowymi dzieci (zwłaszcza młodszych), przez co przejawiają one tendencję do przywoływania wydarzeń z najbliższej przeszłości, tych, które dopiero co miały miejsce. Dlatego też zdecydowanie bardziej zasadne jest proszenie dzieci o przywołanie zdarzeń konkretnych, związanych $\mathrm{z}$ teraźniejszością. W związku z tym wszystkie obrazki przedstawiają sytuacje znane dziecku $\mathrm{z}$ jego codziennego życia. Pełna wersja kwestionariusza znajduje się w Zataczniku 2.

\section{WŁAŚCIWOŚCI PSYCHOMETRYCZNE OPCO-D}

Ocenę psychometrycznych właściwości skali OPCO-D wykonano w siedmiu krokach. W pierwszym kroku przedstawiono statystyki opisowe oraz omówiono rozkład wyników. W kroku drugim za pomocą analizy równoległej zweryfikowano wymiarowość skali, aby potwierdzić, że OPCO-D mierzy pięć podstawowych wymiarów osobowości. W trzecim kroku poddano ocenie strukturę czynnikową każdej ze skal, używając do tego konfirmacyjnej analizy czynnikowej. Założono, że pozycje testowe wchodzące w skład każdej ze skal są odpowiednimi wskaźnikami zmiennych latentnych, co będzie wyrażone w istotnych ładunkach czynnikowych oraz dobrym dopasowaniu testowanego modelu. W czwartym kroku przedstawiono interkorelacje między badanymi skalami. W piątym kroku, korelując zmienną latentną ze skalą obliczoną z klucza, zweryfikowano rzetelność pomiaru. Założono, że wpływ błędu pomiaru na uzyskane wyniki będzie niewielki, co pozwoli zachować większą pewność w interpretacji uzyskanych wyników. W szóstym kroku zbadano trafność pomiaru, 
porównując samoopis dziecka $z$ opisem nauczyciela. Założono, że uzyskane wyniki będą częściowo zbieżne, potwierdzając, że poszczególne skale OPCO-D faktycznie odnoszą się do pięciu podstawowych cech osobowości. W ostatnim kroku zweryfikowano, czy w poszczególnych skalach kwestionariusza OPCO-D występują różnice międzypłciowe.

\section{CHARAKTERYSTYKA BADANEJ PRÓBY I PROCEDURA BADANIA}

W badaniach referowanych w niniejszym artykule wzięło udział łącznie $N=863$ dzieci w późnym wieku szkolnym. Wyniki pochodzące z nieklinicznej próby $n=600$ dzieci w wieku od 6. do 10 . roku życia $(M=8,41 ; S D=1,04 ; 49,2 \%$ dziewczynek) zostały wykorzystane do oceny struktury czynnikowej kwestionariusza OPCO-D oraz do oceny rzetelności pomiaru. Wyniki pochodzące z próby $n=283$ dzieci w wieku od 7 do 10 lat $(M=8,86$; $S D=0,81 ; 53,2 \%$ dziewczynek) zostały wykorzystane do stworzenia norm dla kwestionariusza OPCO-D. Ponadto z próby $n=283$ dzieci wybrano podgrupę $n=121$ dzieci, których osobowość została poddana dodatkowemu opisowi przez nauczycieli.

Badania zostały przeprowadzone w planie grupowym w szkołach podstawowych w województwie mazowieckim. Przed rozpoczęciem badań dyrektorowie szkół oraz prawni opiekunowie uczestników zostali poinformowani o ich celu, przebiegu, wyjaśnione zostały aspekty badania oraz udzielone odpowiedzi na zadane pytania. Instytucją pośredniczącą w uzyskaniu zgody na udział dzieci w badaniu była szkoła, reprezentowana przez dyrekcję. Opiekunowie prawni uczniów wyrazili zgodę na ich udział w badaniu.

Badanie miało charakter anonimowy i zostało przeprowadzone grupowo podczas zajęć lekcyjnych (maksymalnie jedna godzina lekcyjna). Osoba przeprowadzająca badanie upewniała się, czy instrukcja jest dla wszystkich zrozumiała. Jeśli istniała taka potrzeba, to każdorazowo były udzielane dodatkowe wyjaśnienia. Priorytetem było to, aby dzieci, mimo że badanie było grupowe, udzielały odpowiedzi samodzielnie i nie konsultowały się między sobą. Dodatkowo przestrzegana była zasada dobrowolności uczestniczenia w badaniu. Uczestnicy zostali poinformowani o możliwości rezygnacji z udziału w badaniu w dowolnym jego momencie.

\section{STATYSTYKI OPISOWE I ROZKŁAD WYNIKÓW}

Statystyki opisowe oraz test normalności rozkładu Kołmogorowa-Smirnowa przedstawiono w tabeli 2. Najwyższe wyniki odnotowano dla ugodowości i sumienności - zdecydowana większość badanych uzyskała wyniki zbliżone do maksymalnych. Nieco niższe wartości zaobserwowano dla ekstrawersji. Wyniki dla otwartości były zbliżone do przeciętnych. Wyniki dla neurotyczności były niskie w przypadku większości badanych dzieci. Test normalności rozkładu wskazał, że każda ze skal OPCO-D odbiega od rozkładu normalnego. W przypadku ugodowości, sumienności i ekstrawersji rozkłady były lewostronne, w przypadku neurotyczności zaś - prawostronne. Większość wyników ugodowości i sumienności była zorganizowana w bliskiej odległości od średniej. Podsumowując, skale kwestionariusza OPCO-D mogą w sposób ograniczony dyskryminować dzieci osiągające wyniki niskie i wysokie, szczególnie w odniesieniu do ugodowości i sumienności. 
Tabela 2. Statystyki opisowe oraz test normalności rozkładu skal kwestionariusza OPCO-D

\begin{tabular}{lcccccccc}
\hline & $\boldsymbol{M}$ & SD & Min & Max & $\boldsymbol{S}$ & $\boldsymbol{K}$ & $\boldsymbol{Z}$ & $\boldsymbol{p}$ \\
\hline Neurotyczność & 1,41 & 0,45 & 1 & 3 & 1,01 & 0,20 & 0,19 & 0,001 \\
\hline Ekstrawersja & 2,62 & 0,37 & 1 & 3 & $-0,97$ & 0,76 & 0,19 & 0,001 \\
\hline Otwartość & 2,21 & 0,45 & 1 & 3 & $-0,25$ & $-0,50$ & 0,13 & 0,001 \\
\hline Ugodowość & 2,77 & 0,32 & 1 & 3 & $-1,53$ & 2,23 & 0,30 & 0,001 \\
\hline Sumienność & 2,75 & 0,36 & 1 & 3 & $-1,70$ & 2,93 & 0,29 & 0,001 \\
\hline
\end{tabular}

\section{OCENA WYMIAROWOŚCI OPCO-D}

W literaturze istnieje wiele sposobów na ocenę wymiarowości narzędzi psychologicznych. Metody, które są często wykorzystywane, takie jak reguła Kaisera (1960) bądź też ocena wykresu osypiska (Cattell, 1966), są jednak obarczone pewnymi trudnościami. Reguła Kaisera (1960) mówi o tym, że należy wyodrębnić wszystkie czynniki, których wartości własne przekraczają „1”. Jednak jak wykazują badania symulacyjne, analiza ta jest skuteczna (tzn.: poprawnie identyfikuje liczbę wymiarów) w mniej niż 10\% sytuacji (Ruscio, Roche, 2012). Wykres osypiska przedstawia wartości własne czynników, łącząc je linią. Interpretując go, należy odszukać miejsce załamania wykresu i wyodrębnić tyle czynników, ile znajdowało się przed tym miejscem. Pomimo że jest on metodą znacznie skuteczniejszą, jego interpretacja jest obarczona ryzykiem subiektywności interpretacji. $Z$ tego względu w literaturze najczęściej sugeruje się wybór innej metody, jaką jest analiza równoległa (Horn, 1965). Analiza równoległa to wykres osypiska wzbogacony o tysiące równoległych symulacji na podstawie obserwowalnych danych wejściowych. W interpretacji wyników analizy równoległej, identyfikując liczbę czynników, należy odnaleźć miejsce, w którym symulowane dane zaczynają mieć większą wartość własną niż dane wejściowe. Metoda ta jest jedną z najskuteczniejszych metod oceny wymiarowości i uchodzi za złoty standard (Ruscio, Roche, 2012), dlatego też interpretując wymiarowość OPCO-D, prezentujemy jej wyniki na rysunku 4.

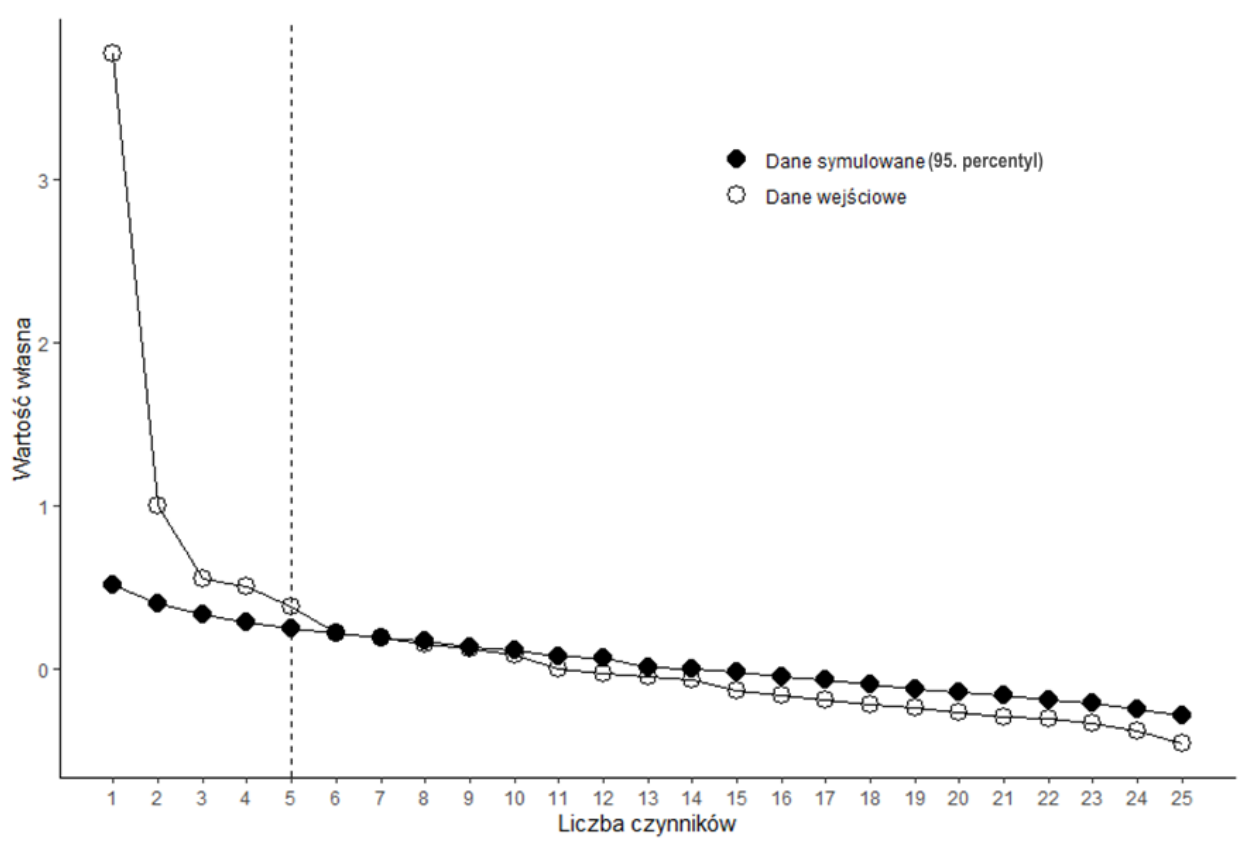

Rysunek 4. Wyniki analizy równoległej OPCO-D. 
$\mathrm{Na}$ podstawie wykresu analizy równoległej wyraźnie widać, że jest pięć czynników, których wartości własne obliczone na podstawie danych wejściowych przekraczają wartości własne czynników obliczonych na podstawie symulacji. Analiza równoległa potwierdziła zatem hipotezę mówiącą o tym, że OPCO-D mierzy pięć odrębnych czynników.

\section{OCENA STRUKTURY CZYNNIKOWEJ}

Analizując strukturę czynnikową OPCO-D, przeprowadzono pięć konfirmacyjnych analiz czynnikowych - osobno dla każdej ze skal. Pomimo faktu, że istniała możliwość przetestowania jednego modelu, w którym zostałyby uwzględnione wszystkie cechy jednocześnie, w literaturze można się spotkać z doniesieniami, że nie jest to optymalna strategia oceny cech Wielkiej Piątki (Marsh i in., 2010)1. Ponadto przy tym sposobie oceny struktury czynnikowej możliwa jest kontrola błędu pomiaru każdej z tych skal, co zostanie szczegółowo omówione $\mathrm{w}$ akapicie na temat rzetelności pomiaru. W konfirmacyjnej analizie czynnikowej porównuje się hipotetyczny model z modelem zerowym (czyli takim, w którym nie przyjmuje się żadnych założeń). Innymi słowy, sprawdza się, czy zakładana struktura opisuje dane lepiej niż model zerowy. W ocenie tej stosuje się kilka współczynników. Statystyka $\chi^{2}$ informuje o dobrym dopasowaniu proponowanego modelu do danych, jeśli jej wartość jest nieistotna. Statystyka Comparative Fit Index (CFI) informuje o dobrym dopasowaniu do danych, jeśli jej wartości przekraczają 0,90. Statystyka Root Mean Square Error of Approximation (RMSEA) informuje z kolei o dobrym dopasowaniu, jeśli jej wartości są mniejsze niż 0,08 (Byrne, 1994). Wszystkie te współczynniki obliczone dla pięciu skal przedstawiono w tabeli 3. Do analizy wykorzystano program Mplus (Muthén, Muthén, 2012) w wersji 7.2. Ponieważ OPCO-D zawiera tylko trzy możliwe opcje odpowiedzi, do estymacji testowanych modeli wykorzystano macierz korelacji polychorycznych, stosując odpowiednio estymator WLSMV (weighted least squares with means and variance adjusted). Do estymacji braków danych posłużono się estymacją pełnej informacji największej wiarygodności.

Tabela 3. Współczynniki dopasowania testowanych modeli do danych

\begin{tabular}{lcccc}
\hline \multicolumn{1}{c}{ Skala } & $\mathbf{X}_{(5)}^{2}$ & $\boldsymbol{p}$ & CFI & RMSEA \\
\hline Neurotyczność & 11,25 & 0,047 & 0,989 & 0,046 \\
\hline Ekstrawersja & 10,20 & 0,070 & 0,980 & 0,042 \\
\hline Otwartość & 14,30 & 0,014 & 0,915 & 0,056 \\
\hline Ugodowość & 25,35 & 0,001 & 0,961 & 0,082 \\
\hline Sumienność & 9,94 & 0,077 & 0,978 & 0,041 \\
\hline
\end{tabular}

Statystyka $\chi^{2}$ okazała się nieistotna dla ekstrawersji oraz sumienności. Należy jednak mieć na uwadze, że jest ona wrażliwa na wielkość próby, stąd zalecane jest interpretowanie jej wyników w odniesieniu do pozostałych statystyk (Kline, 2015). Wartości statystyk CFI oraz RMSEA okazały się odpowiednie dla wszystkich skal z wyjątkiem ugodowości, dla której RMSEA minimalnie przekroczyła oczekiwany próg. W tabeli 4 przedstawiono wystandaryzowane ładunki czynnikowe dla każdej ze skal.

1 Testowany model pięcioczynnikowy, bez wprowadzania żadnych dodatkowych poprawek, okazal się dobrze dopasowany w odniesieniu do statystyki RMSEA $(0,043[0,038 ; 0,048])$ oraz na progu dobrego dopasowania na podstawie statystyki CFI $(0,888)$. 
Tabela 4. Wystandaryzowane ładunki czynnikowe dla analizowanych skal OPCO-D

\begin{tabular}{lccccc}
\hline & Neurotyczność & Ekstrawersja & Otwartość & Ugodowość & Sumienność \\
\hline Pozycja 1 & 0,67 & 0,50 & 0,48 & 0,76 & 0,72 \\
\hline Pozycja 2 & 0,76 & 0,66 & 0,65 & 0,78 & 0,70 \\
\hline Pozycja 3 & 0,57 & 0,95 & 0,37 & 0,70 & 0,53 \\
\hline Pozycja 4 & 0,73 & 0,39 & 0,56 & 0,62 & 0,40 \\
\hline Pozycja 5 & 0,53 & 0,29 & 0,17 & 0,48 & 0,59 \\
\hline
\end{tabular}

Wszystkie ładunki czynnikowe okazały się istotne statystycznie. Siła niemal wszystkich okazała się odpowiednia $(\geq 0,30)$. Wyjątkiem jest pozycja numer 5 ekstrawersji (której ładunek czynnikowy ulokował się na granicy akceptowalności) oraz otwartości. Uzyskane wyniki zdają się zatem potwierdzać trafność treściową OPCO-D.

\section{INTERKORELACJE SKAL}

W tabeli 5 przedstawiono interkorelację skal. Prezentowane wyniki odnoszą się do średnich wyliczonych bezpośrednio z klucza (poniżej przekątnej), ale również i do zmiennych latentnych (powyżej przekątnej), których wyniki wyodrębniono w trakcie oceny struktury czynnikowej.

Tabela 5. Interkorelacje skal

\begin{tabular}{lccccc}
\hline & Neurotyczność & Ekstrawersja & Otwartość & Ugodowość & Sumienność \\
\hline Neurotyczność & & $-0,21$ & $-0,30$ & $-0,44$ & $-0,58$ \\
\hline Ekstrawersja & $-0,25$ & & 0,16 & 0,33 & 0,14 \\
\hline Otwartość & $-0,25$ & 0,21 & & 0,26 & 0,36 \\
\hline Ugodowość & $-0,41$ & 0,38 & 0,24 & & 0,49 \\
\hline Sumienność & $-0,56$ & 0,18 & 0,34 & 0,48 & \\
\hline
\end{tabular}

Adnotacja. Interkorelacje dla zmiennych obliczonych z klucza przedstawiono poniżej przekątnej. Interkorelacje dla zmiennych latentnych przedstawiono powyżej przekątnej. Wszystkie prezentowane współczynniki są istotne na poziomie $p<0,001$.

Zgodnie z oczekiwaniami neurotyczność korelowała ujemnie ze wszystkimi pozostałymi cechami. Najwyższe współczynniki korelacji odnotowano między neurotycznością a sumiennością, najniższe zaś między sumiennością i ekstrawersją oraz otwartością i ekstrawersją.

\section{RZETELNOŚĆ POMIARU}

Jednym z najczęściej wykorzystywanych współczynników w ocenie spójności wewnętrznej jest współczynnik alfa Cronbacha (1951). Pomimo swojej popularności jest on również często krytykowany (Sijtsma, 2009) ze względu na szereg ograniczeń, takich jak na przykład trudne do zrealizowania założenie o równości wielkości ładunków czynnikowych wszystkich pozycji testowych. W związku z ograniczeniami Saris i Gallhofer (2007) zaproponowali, aby rzetelność pomiaru traktować jako stopień podobieństwa (a więc - korelacji) między średnią z pozycji testowych wyliczonych zgodnie z kluczem (w której nie kontroluje się błędu pomiaru) a zmienną latentną (której oszacowanie uwzględnia błędy pomiaru). Współczynnik korelacji między tymi dwiema zmiennymi informuje zatem o wpływie błędu pomiaru. Przykładowo współczynnik korelacji równy 0,70 informuje, że 30\% informacji 
pochodzi z błędu pomiaru. Współczynniki rzetelności dla każdej ze skal obliczone tą metodą przedstawiono w tabeli 6 .

Tabela 6. Współczynniki rzetelności pomiaru dla skal kwestionariusza OPCO-D

\begin{tabular}{cc}
\hline Skala & Współczynnik rzetelności \\
\hline Neurotyczność & 0,98 \\
\hline Ekstrawersja & 0,92 \\
\hline Otwartość & 0,93 \\
\hline Ugodowość & 0,97 \\
\hline Sumienność & 0,97
\end{tabular}

Adnotacja. Wszystkie korelacje są istotne na poziomie $p<0,001$.

Wszystkie współczynniki korelacji były większe niż 0,90. Oznacza to, że wpływ błędu pomiaru był minimalny. Wyniki skal obliczone za pomocą kwestionariusza OPCO-D charakteryzują się wysoką rzetelnością pomiaru.

\section{TRAFNOŚĆ POMIARU}

Aby ocenić trafność pomiaru, wykorzystano wersję obserwacyjną kwestionariusza Big Five Inventory for Children (BFQ-C; Barbaranelli i in., 2003). Składa się ona z 65 pozycji testowych, w odniesieniu do których obserwator (w przypadku opisywanego badania - nauczyciel) wyraża opinię o dziecku. Wyniki porównań przedstawiono w tabeli 7.

Tabela 7. Współczynniki korelacji między samoopisem OPCO-D a opisem nauczyciela BFQ-C

\begin{tabular}{|c|c|c|c|c|c|c|}
\hline & & \multicolumn{5}{|c|}{ BFQ-C } \\
\hline & & $\mathbf{N}$ & E & 0 & U & $S$ \\
\hline \multirow{5}{*}{ 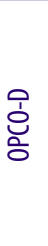 } & Neurotyczność & $0,46^{* * *}$ & 0,02 & $-0,05$ & $-0,26^{* *}$ & $-0,13$ \\
\hline & Ekstrawersja & $-0,08$ & $0,55^{* * *}$ & $0,27^{* *}$ & $0,37^{* * *}$ & $0,31^{* *}$ \\
\hline & Otwartość & $-0,05$ & $0,33^{* * *}$ & $0,38^{* * *}$ & $0,26^{* *}$ & $0,38^{* * *}$ \\
\hline & Ugodowość & $-0,24^{* *}$ & $0,54^{* * *}$ & $0,39 * * *$ & $0,66^{* * *}$ & $0,49^{* * *}$ \\
\hline & Sumienność & $-0,05$ & $0,42^{* * *}$ & $0,48^{* * *}$ & $0,33^{* * *}$ & $0,43^{* * *}$ \\
\hline
\end{tabular}

${ }^{*} p<0,05 ;{ }^{* *} p<0,01 ; * * * 0<0,001$.

Wszystkie współczynniki korelacji między tymi samymi cechami mierzonymi w odmienny sposób okazały się, zgodnie z oczekiwaniami, istotne statystycznie, choć otwartość mierzona $\mathrm{z}$ wykorzystaniem OPCO-D okazała się korelować równie silnie z sumiennością mierzoną BFQ-C w wersji dla nauczyciela. W przypadku korelacji sumienności mierzonej OPCO-D z otwartością mierzoną BFQ-C w wersji dla nauczyciela korelacja ta okazała się natomiast silniejsza od oczekiwanej. Może to świadczyć o tym, że dla nauczyciela zachowania ucznia związane z otwartością na doświadczenie (np. zaciekawienie nowymi tematami lekcji, rozwój zainteresowań) mogą się wiązać z sumiennością, której przejawy również łatwo jest zaobserwować w środowisku szkolnym. Pojawia się zatem czynnik tzw. dobrego ucznia, zainteresowanego nauką szkolną i sumiennie wykonującego swoje uczniowskie obowiązki.

Najsilniejszą korelację odnotowano w zakresie ugodowości. Siła korelacji poszczególnych współczynników, wydawać by się mogło, jest niższa od oczekiwanej (tj. 0,70), jednakże na obraz ten miał wpływ szereg czynników zakłócających. Dzieci oraz nauczyciele wypełniali zupełnie różne kwestionariusze (OPCO-D vs BFQ-C) - mogło to doprowadzić do wystąpienia zniekształceń spowodowanych zastosowaną metodą (Podsakoff, MacKenzie, 
Podsakoff, 2012). Ponadto nauczyciele szacowali cechy osobowości wielu dzieci, co mogło skutkować licznymi zniekształceniami i spowodować, że opisy nauczycieli będą mniej dokładne.

\section{RÓŻNICE MIĘDZYPŁCIOWE}

W tabeli 8 przedstawiono różnice międzypłciowe w poziomie nasilenia poszczególnych cech osobowości mierzonych za pomocą kwestionariusza OPCO-D. Nie odnotowano istotnych różnic w zakresie neurotyczności i ekstrawersji, uwidoczniono je natomiast w zakresie pozostałych cech. Dziewczynki okazały się bardziej otwarte, ugodowe oraz sumienne niż chłopcy. Wielkość zaobserwowanego efektu była jednak nieznaczna.

Tabela 8. Różnice międzypłciowe

\begin{tabular}{cccc}
\hline & $t_{(598)}$ & $\boldsymbol{p}$ & $\boldsymbol{D}$ \\
\hline Neurotyczność & 1,03 & 0,306 & 0,08 \\
\hline Ekstrawersja & $-0,45$ & 0,656 & 0,03 \\
\hline Otwartość & $-2,85$ & 0,005 & 0,22 \\
\hline Ugodowość & $-4,42$ & 0,001 & 0,34 \\
\hline Sumienność & $-4,28$ & 0,001 & 0,33 \\
\hline
\end{tabular}

\section{PODSUMOWANIE}

Narzędzie pomiarowe dostosowane do poziomu rozwojowego osób badanych, którymi są dzieci, wydaje się interesującym wyzwaniem psychometrycznym. Wyniki prac nad kwestionariuszem OPCO-D, opisane w niniejszym artykule, pokazują, że OPCO-D z powodzeniem można traktować jako most łączący bardziej interakcyjne badania dzieci młodszych z kwestionariuszami bazującymi na kodzie werbalnym dla dzieci starszych (Ablow, Measelle, 1993; Barbaranelli i in., 2003). Można uznać, że kwestionariusz ten stanowi satysfakcjonujące uzupełnienie istniejącej narzędziowej luki w sposobach pomiaru cech osobowości u dzieci, zwłaszcza między 7. a 10. rokiem życia.

Przeprowadzone analizy potwierdziły możliwość dokonania rzetelnego i trafnego pomiaru pięciu głównych cech osobowości w okresie późnego dzieciństwa $\mathrm{z}$ wykorzystaniem kwestionariusza OPCO-D. Jednak należy wspomnieć o korelacji sumienności z otwartością w porównaniu samoopisu z opisem nauczyciela. Analogiczne wyniki uzyskali już w swoich badaniach Mervielde i De Fruyt (2000). Należy pamiętać, że w okresie późnego dzieciństwa większość aktywności dziecka skupiona jest wokół szkoły. Tym samym te dwa czynniki, czyli sumienność i otwartość, związane z nauką, ciekawością i zaangażowaniem $\mathrm{w}$ realizację zadań, są w tym czasie silnie promowane, zachowania $\mathrm{z}$ nimi związane i obserwowane przez nauczyciela mogą natomiast tworzyć pewien rodzaj metaczynnika.

Do artykułu załączone zostały: procedura badania (Zatacznik 1), kwestionariusz OPCO-D (Zatqcznik 2), klucz (Zatacznik 3), opracowane tymczasowe i orientacyjne normy stenowe bez podziału na wiek i płeć (Zatacznik 4) oraz interpretacje wyników (Zatacznik 5). 


\section{BIBLIOGRAFIA}

Ablow, J. C., Measelle, J. R. (1993). Berkeley Puppet Interview: administration and scoring system manuals. Berkeley: University of California. Pobrane z https://hostingfasr838.weebly.com/berkeley-puppet-interview-manual.html

Barbaranelli, C., Caprara, G., Rabasca, A., Pastorelli, C. (2003). A questionnaire for measuring the Big Five in late childhood. Personality and Individual Differences, 34, 645-664. https://doi.org/10.1016/S0191-8869(02)00051-X

Borgers, N., de Leeuw, E., Hox, J. J. (2000). Children as respondents in survey research: cognitive development and response quality. Bulletin of Sociological Methodology (BMS), 66, 60-75. https://doi.org/10.1177/075910630006600106

Byrne, B. M. (1994). Structural equation modeling with EQS and EQS/Windows: Basic concepts, applications, and programming. Thousand Oaks: Sage.

Caspi, A., Roberts, B. W., Shiner, R. L. (2005). Personality development: stability and change. Annual Review of Psychology, 56, 453-484. https:// doi.org/10.1146/annurev.psych.55.090902.141913

Cattell, R. B. (1966). The scree test for the number of factors. Multivariate Behavioral Research, 1, 245-276. https://doi.org/10.1207/ s15327906mbr0102_10

Chan, W., McCrae, R. R., De Fruyt, F., Jussim, L., Löckenhoff, C. E., De Bolle, M., ..., Terracciano, A. (2012). Stereotypes of age differences in personality traits: Universal and accurate? Journal of Personality and Social Psychology, 103, 1050-1066. https://doi.org/10.1037/a0029712

Cieciuch, J. (2010). Pięcioczynnikowa struktura osobowości we wczesnej adolescencji. Studia Psychologica, 10, $251-271$.

Cieciuch, J., Harasimczuk, J., Döring, A. K. (2010). Struktura wartości w późnym dzieciństwie. Psychologia Rozwojowa, 15(2), 33-45.

Costa, P. T., Jr., McCrae, R. (1976). Age differences in personality structure: a cluster analytic approach. Journal of Gerontology, 31, 564-570. https:// doi.org/10.1093/geronj/31.5.564

Cronbach, L. J. (1951). Coefficient alpha and the internal structure of tests. Psychometrika, 16, 297-334. https://doi.org/10.1007/BF02310555

Damon, W., Hart, D. (1982). The development of self-understanding from infancy through adolescence. Child Development, 53, 841-864. https:// doi.org/10.2307/1129122

De Bolle, M., De Fruyt, F., McCrae, R. R., Löckenhoff, C. E., Costa, P. T., Jr., Aguilar-Vafaie, M. E., ..., Terracciano, A. (2015). The emergence of sex differences in personality traits in early adolescence: a cross-sectional, cross-cultural study. Journal of Personality and Social Psychology, 108, 171-185. https://doi.org/10.1037/a0038497

De Fruyt, F., Mervielde, I., Hoekstra, H., Rolland, J. (2000). Assessing adolescents' personality with the NE0 PI-R. Assessment, 7, 329-345. https:// doi.org/10.1177/107319110000700403

del Barrio, V., Carrasco, M. A., Holgado, F. P. (2006). Factor structure invariance in the children's Big Five Questionnaire. European Journal of Psychological Assessment, 22, 158-167. https://doi.org/10.1027/1015-5759.22.3.158

Döring, A. K., Blauensteiner, A., Aryus, K., Drögekamp, L., Bilsky, W. (2010). Assessing values at an early age: The Picture-Based Value Survey for Children. Journal of Personality Assessment, 92, 439-448. https://doi.org/10.1080/00223891.2010.497423

Hendriks, J., Perugini, M., Angleitner, A., Ostendorf, F., Johnson, J., De Fruyt, F., ... Ruisel, I. (2003). The Five-Factor Personality Inventory: crosscultural generalizability across 13 countries. European Journal of Personality, 17, 347-373. https://doi.org/10.1002/per.491

Hershey, M., Hill, D. (1976). Positional response set in pre-adult socialization surveys. Social Science Quarterly, 56, 707-714. https://www.jstor. org/stable/42860424

Horn, J. L. (1965). A rationale and test for the number of factors in. factor analysis. Psychometrika, 30, 179-185. https://doi.org/10.1007/ BF02289447

Kaiser, H. F. (1960). The application of electronic computer to factor analysis. Educational and Psychological Measurement, 20, 141-151. https:// doi.org/10.1177/001316446002000116

Kielar-Turska, M., Białecka-Pikul, M., Skórska, A. (2006). Rozwój zdoIności mentalizacji. Z badań nad związkiem teorii umysłu, sprawności językowych i funkcji zarządzającej. Psychologia Rozwojowa, 11(2), 35-47.

Kline, R. B. (2015). Principles and practice of structural equation modeling. Nowy Jork: The Guilford Press.

Kohnstamm, G. A., Halverson, C. F., Mervielde, I., Avilla, V. (red.). (1998). The LEA Series in Personality and Clinical Psychology. Parental descriptions of child personality: developmental antecendents of the Big Five? Mahwah: Erlbaum.

Kołodziejczyk, A. (2011). Późne dzieciństwo - młodszy wiek szkolny. W: J. Trempała (red.), Psychologia rozwoju człowieka. Podręcznik akademicki (s. 235-258). Warszawa: PWN.

Maćkiewicz, M., Cieciuch, J. (2012). Jak mierzyć cechy Wielkiej Piątki u dzieci? Prace nad Obrazkowym pomiarem cech osobowości dzieci (OPCO-D). Psychologia Rozwojowa, 17(3), 69-82. https://doi.org/10.4467/20843879PR.12.019.0638

Marsh, H. W., Lüdtke, 0., Muthén, B., Asparouhov, T., Morin, A. J. S., Trautwein, U., Nagengast, B. (2010). A new look at the Big-Five factor structure through exploratory structural equation modeling. Psychological Assessment, 22, 471-491. https://doi.org/10.1037/a0019227

McCrae, R. R. (2001). Trait psychology and culture: exploring intercultural comparisons. Journal of Personality, 69, 819-846. https://doi. org/10.1111/1467-6494.696166 
McCrae, R. R. (2002). Cross-cultural research on the five-factor model of personality cross-cultural research on the five-factor model of personality. Online Readings in Psychology and Culture, 4, 1-12. https://doi.org/10.9707/2307-0919.1038

McCrae, R., Costa, P. T., Jr. (1997). Personality trait structure as a human universal. American Psychologist, 52, 509-516. https://doi.org/10.1037/ 0003-066X.52.5.509

McCrae, R., Costa, P. T., Jr. (2005). Osobowość dorosłego człowieka. Perspektywa teorii pięcioczynnikowej. Kraków: WAM.

McCrae, R., Terracciano, A., 78 współpacowników Personality Profiles of Cultures Project (2005). Universal features of personality traits from the observer's perspective: data from 50 cultures. Journal of Personality and Social Psychology, 88, 547-561. https://doi.org/10.1037/00223514.88.3.547

Measelle, J. R., Ablow, J. A., Cowan, P. A., Cowan, C. P. (1998). Assessing young children's views of their academic, social, and emotional lives: an evaluation of the Berkeley Puppet Interview. Child Development, 69, 1556-1576. https://doi.org/10.1111/j.1467-8624.1998.tb06177.x

Measelle, J. R., John, O. P., Ablow, J. C., Cowan, P. A., Cowan, C. P. (2005). Can children provide coherent, stable, and valid self-reports on the Big Five dimensions? A longitudinal study from ages 5 to 7 . Journal of Personality and Social Psychology, 89, 90-106. https://doi.org/10.1037/00223514.89.1.90

Mervielde, I., Asendorpf, J. B. (2000). Variable-centred and person-centred approaches to childhood personality. W: S. E. Hampson (red.), Advances in personality psychology (t. 1, s. 37-76). Londyn: Psychology Press.

Mervielde, I., De Fruyt, F. (1999). Construction of the Hierarchical Personality Inventory for Children (HiPICS). W: I. Mervielde, I. Deary, F. De Fruyt, F. Ostendorf (red.), Personality psychology in Europe. Proceedings of the Eight European Conference on Personality Psychology (s. 107-127). Tilburg: Tilburg University Press.

Mervielde, I., De Fruyt, F. (2000). The Big Five personality factors as a model for the structure of children's peer nominations. European Journal of Personality, 14, 91-106. https://doi.org/10.1002/(SICI)1099-0984(200003/04)14:2<91::AID-PER356>3.0.C0;2-Z Muris, P., Meesters, C., Diederen, R. (2005). Psychometric properties of the Big Five Questionnaire for Children (BFQ-C) in a Dutch sample of young adolescents. Personality and Individual Differences, 38, 1757-1769. https://doi.org/10.1016/j.paid.2004.11.018

Muthén, L., Muthén, B. (2012). Mplus user's guide (Sixth edition). Los Angeles: Muthén \& Muthén.

Piaget, J. (1960). The psychology of intelligence. Paterson: Littlefield, Adams.

Podsakoff, P. M., MacKenzie, S. B., Podsakoff, N. P. (2012). Sources of method bias in social science research and recommendations on how to control it. Annual Review of Psychology, 63, 539-569. https://doi.org/10.1146/annurev-psych-120710-100452

Ruscio, J., Roche, B. (2012). Determining the number of factors to retain in an exploratory factor analysis using comparison data of a known factorial structure. Psychological Assessment, 24, 282-292. https://doi.org/10.1037/a0025697

Saris, W. E., Gallhofer, I. N. (2007). Design, evaluation, and analysis of questionnaires for survey research. Hoboken: Willey.

Shiner, R., Caspi, A. (2003). Personality differences in childhood and adolescence: Measurement, development, and consequences. Journal of Child Psychology and Psychiatry, 44, 2-32. https://doi.org/10.1111/1469-7610.00101

Sijtsma, K. (2009). On the use, the misuse, and the very limited usefulness of Cronbach's alpha. Psychometrika, 74, 107-120. https://doi. org/10.1007/s11336-008-9101-0

Stefańska-Klar, R. (2005). Późne dzieciństwo. Młodszy wiek szkolny. W: B. Harwas-Napierała, J. Trempała (red.), Psychologia rozwoju człowieka. Charakterystyka okresów życia człowieka (t. 2, s. 130-162). Warszawa: PWN.

Zawadzki, B., Strelau, J., Szczepaniak, P., Śliwińska, M. (1998). Inwentarz Osobowości NE0-FFI Costy i Mccrae:Adaptacja polska. Podręcznik. Warszawa: Pracownia Testów Psychologicznych PTP. 


\section{ANEKS}

\section{ZAŁĄCZNIK 1. PRZEZNACZENIE I OPIS KWESTIONARIUSZA, OPIS PROCEDURY BADANIA, OBLICZANIA I INTERPRETOWANIA WYNIKÓW OPCO-D}

\section{Przeznaczenie i opis kwestionariusza}

Kwestionariusz OPCO-D jest przeznaczony dla dzieci w wieku od 6. do 10. roku życia. Materiał testowy składa się z kwestionariusza oraz klucza do obliczania wyników. Kwestionariusz OPCO-D zawiera instrukcję i 25 pozycji testowych, które tworzą pięć skal odpowiadających czynnikom Pięcioczynnikowego Modelu Osobowości, tj. skalę ekstrawersji, skalę neurotyczności, skalę otwartości, skalę sumienności i skalę ugodowości. W skład każdej ze skal wchodzi pięć pozycji. Na pierwszej stronie przedstawiony jest główny bohater, który znajduje się na każdym $\mathrm{z}$ obrazków i z którym osoba badana ma za zadanie się zidentyfikować. Zawarta jest tam także instrukcja oraz metryczka. Osoba badana wybiera w każdej pozycji jeden z obrazków, na którym główny bohater (czyli osoba w szaliku w paski) zachowuje się podobnie do niej. Kiedy nie może się zdecydować na żaden z nich, może wybrać odpowiedź różnie.

\section{Procedura badania kwestionariuszem}

Kwestionariusz OPCO-D przeznaczony jest do badań grupowych oraz indywidualnych. Badanie zajmuje średnio około 15-20 minut, ale czas nie jest ograniczony. Osoby badane w zdecydowanej większości nie zgłaszały trudności w rozumieniu pozycji testowych. Jeśli jednak takie trudności się pojawią, to osoba przeprowadzająca badanie może udzielić wyjaśnień osobie badanej. Przed odebraniem arkusza testowego należy się upewnić, czy osoba badana ustosunkowała się do każdej pozycji testowej oraz czy zawsze wybierała tylko jedną odpowiedź.

\section{Obliczanie i interpretacja wyników otrzymanych podczas badania kwestionariuszem}

Wyniki surowe otrzymane podczas badania z wykorzystaniem OPCO-D oblicza się zgodnie z kluczem (Zatacznik 3). Należy zsumować punkty dla każdej skali oddzielnie i je uśrednić. Odpowiedzi punktowane są w skali od 1 do 3 punktów. Maksymalna liczba punktów surowych dla każdej skali to 15 . Po podliczeniu wyniku surowego (zsumowanie i uśrednienie) należy przekształcić go w normy na skali stenowej, zgodnie z tabelami norm (Załacznik 4). Normy obliczono bez podziału na wiek i płeć. Należy również podkreślić, że mają one charakter orientacyjny i są tymczasowe. 


\section{ZAŁĄCZNIK 2. KWESTIONARIUSZ OBRAZKOWY POMIAR CECH OSOBOWOŚCI DZIECI}

\section{Jaki jesteś? Jak się zachowujesz?}

OPCO-D 3, Marta Maćkiewicz i Jan Cieciuch, 2013

Na następnych stronach znajdują się opisy różnych sytuacji.

Oto przykładowa sytuacja:

Kiedy pada deszcz....

Sytuacje przedstawione są na obrazkach, na których gtówną rolę odgrywa

ta oto osoba w szaliku w paski,

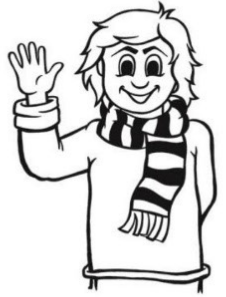

która na dwóch obrazkach robi dwie zupełnie różne rzeczy, np.

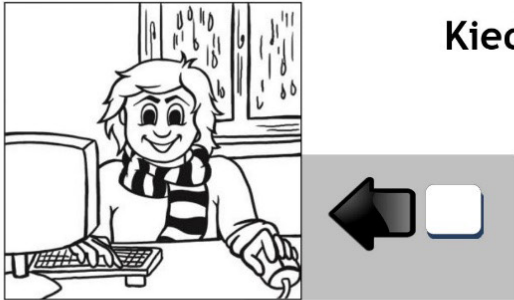

gram w gry na komputerze

\section{różnie}

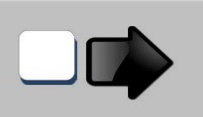

oglądam telewizję

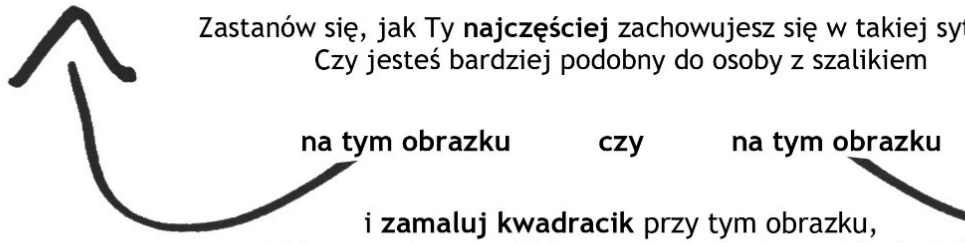

na którym osoba z szalikiem zachowuje się podobnie jak Ty

Uwaga!

W każdej sytuacji możesz wybrać tylko jeden kwadracik.

Jeśli czasem zachowujesz się tak, a czasem tak,

zamaluj środkowy kwadracik z podpisem „różnie”.

Staraj się jednak unikać tego środkowego kwadraciku.

Za każdym razem zastanów się, jak zachowujesz się częściej.

Zanim zaczniesz, wpisz obok

swoje imię, nazwisko, wiek

oraz zaznacz podkreśleniem,

czy jesteś chłopcem czy dziewczyną!

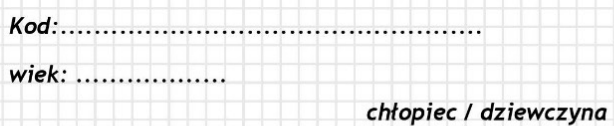

chtopiec / dziewczyna 


\section{A jak zachowujesz się Ty?}

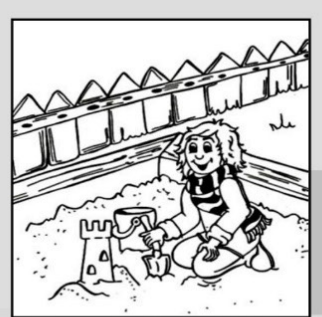

sam/sama

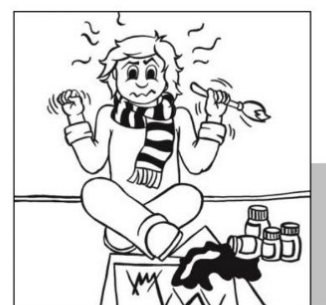

szybko się denerwuję

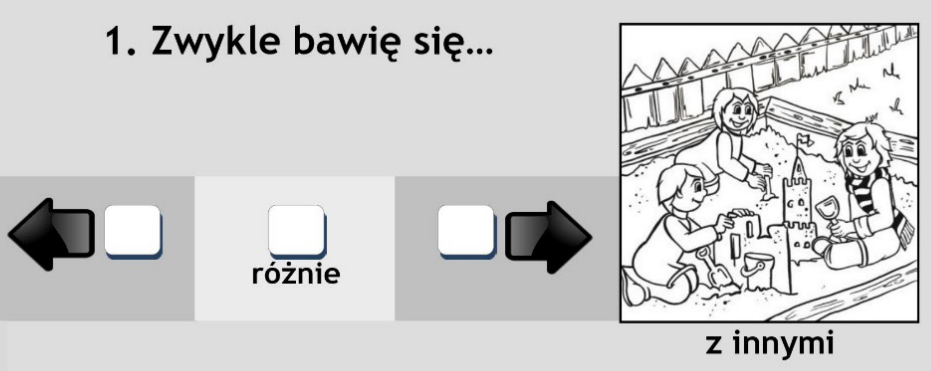

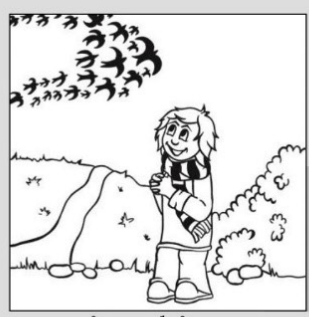

nie robi to na mnie wrażenia
2. Kiedy coś mi nie wychodzi...

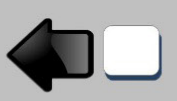

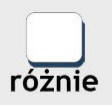
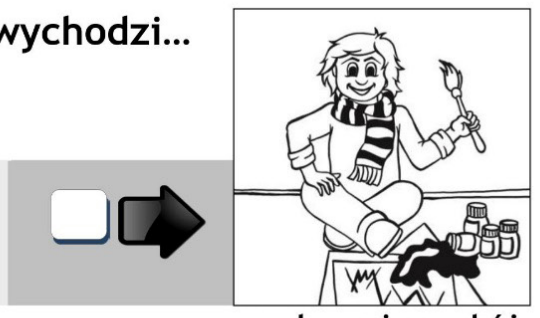

zachowuję spokój

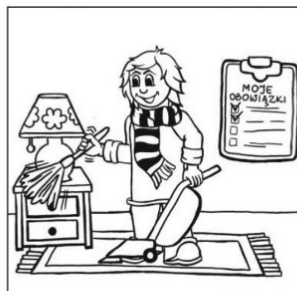

chętnie
3. Kiedy widzę lecące ptaki...
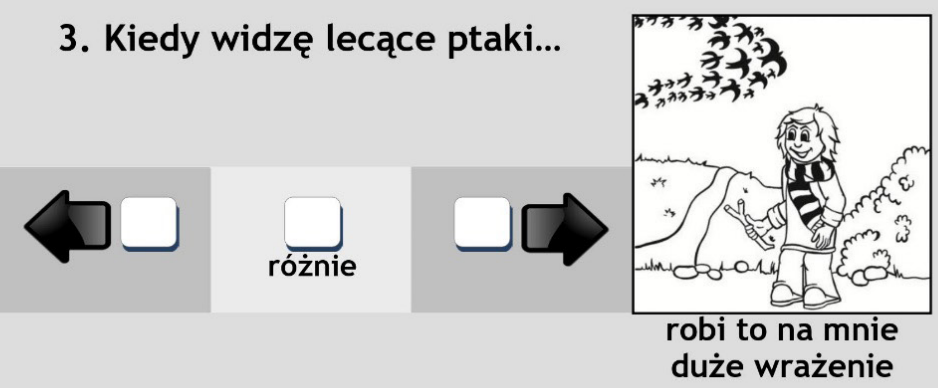

4. Domowe obowiązki wypełniam...
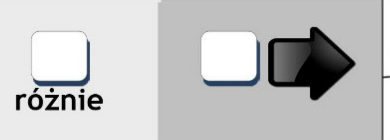

-2 -

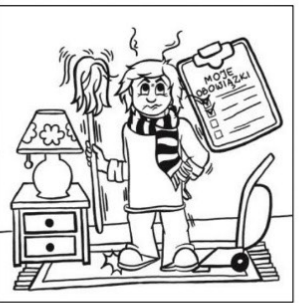

niechętnie 


\section{A jak zachowujesz się Ty?}

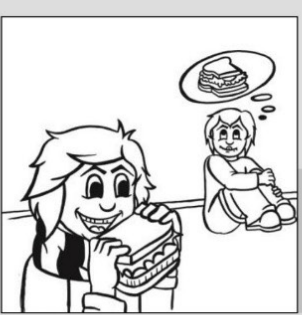

nie zauważam tego

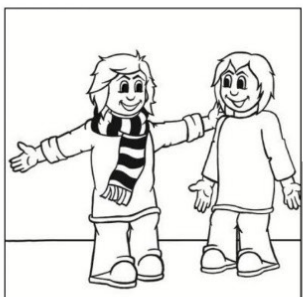

dużo rozmawiam
5. Kiedy ktoś z mojej klasy czegoś potrzebuje...

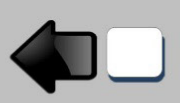

różnie

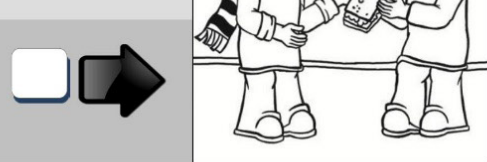

zauważam to i mu pomagam

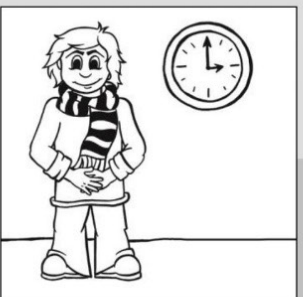

czekam cierpliwie

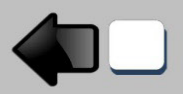

7. Zwykle kiedy na coś czekam...

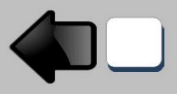

różnie

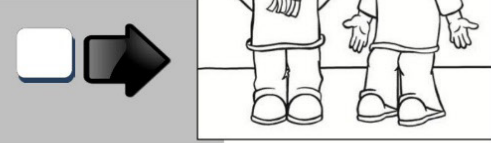

mało rozmawiam

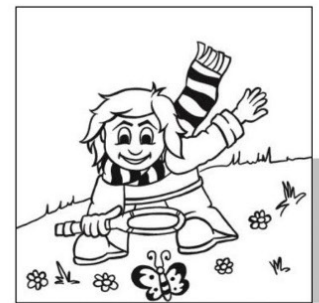

odkrywać coś nowego

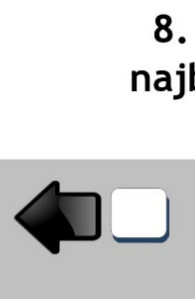

8. Na wycieczce najbardziej lubię...

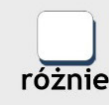

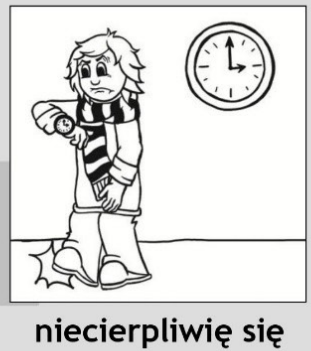




\section{A jak zachowujesz się Ty?}

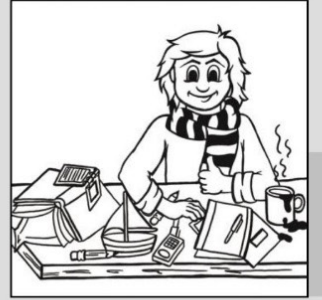

jest bałagan
9. W moim pokoju...

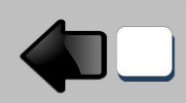

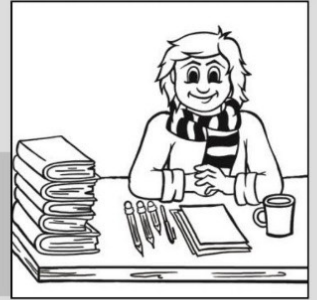

jest porządek

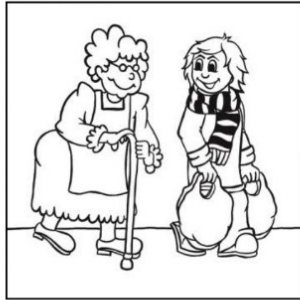

pomagam

10. Kiedy widzę, że mogę komuś pomóc...
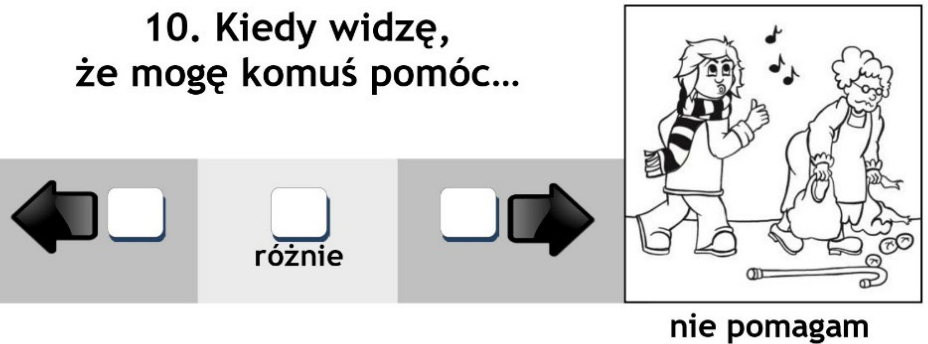

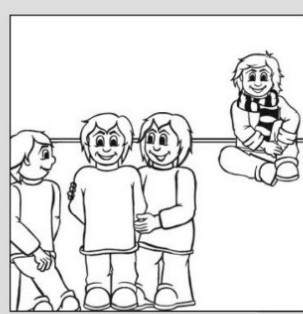

sam/sama

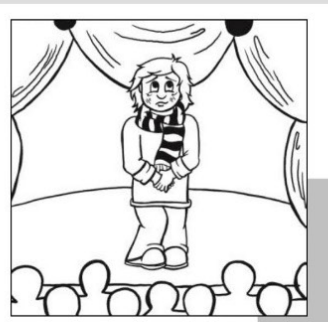

denerwuję się

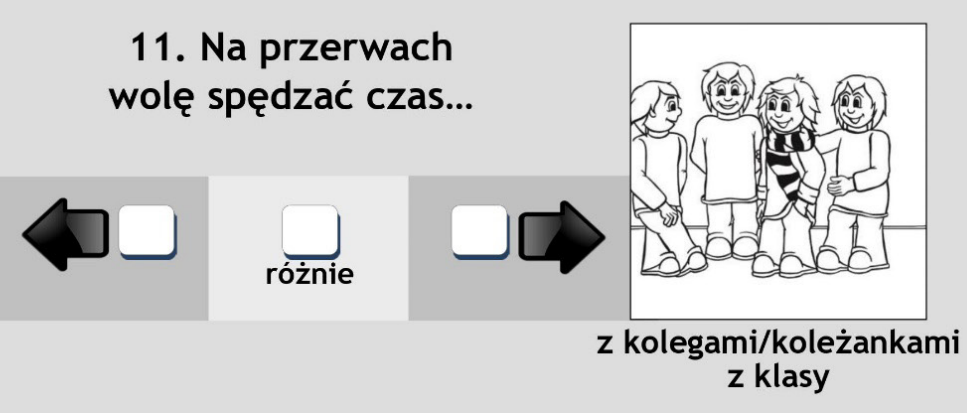

12. Kiedy występuję przed innymi...

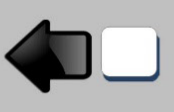

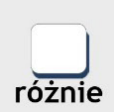

$-4-$

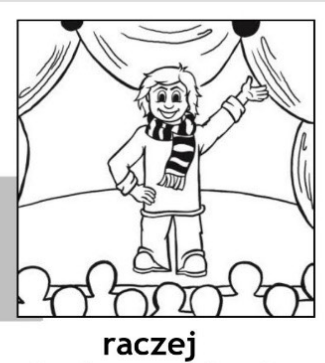

nie denerwuję się 


\section{A jak zachowujesz się Ty?}

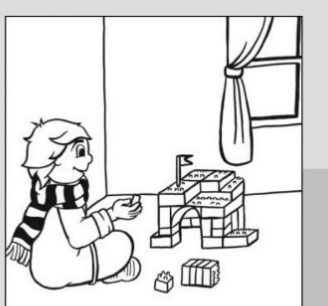

bawię się w ulubioną zabawę

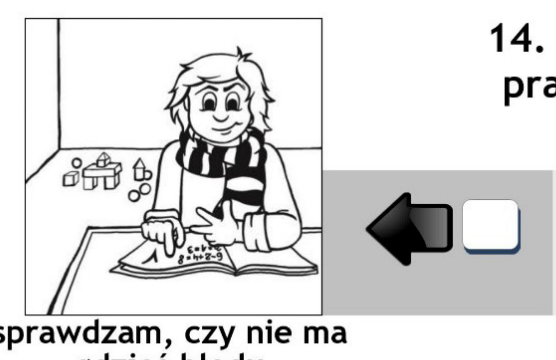
gdzieś błędu

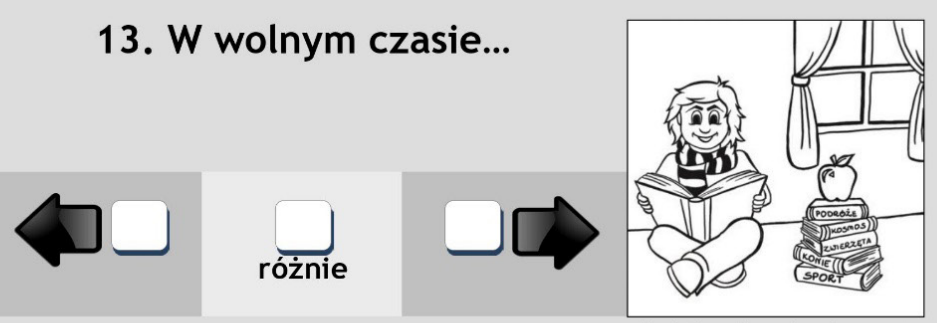

lubię dowiadywać się czegoś nowego

14. Kiedy odrobię pracę domową...

\section{różnie

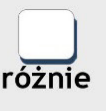

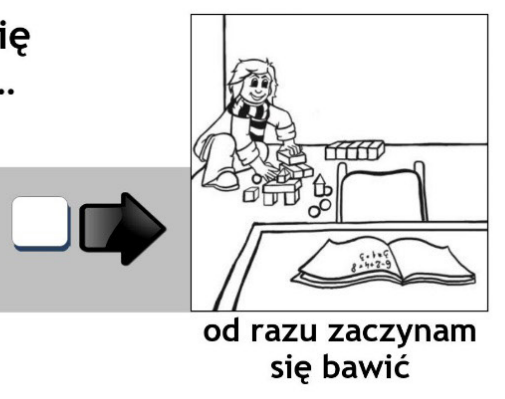

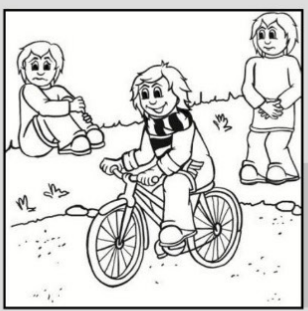

nie pożyczam jej innym
15. Kiedy mam nową rzecz...

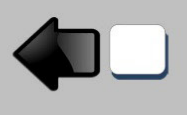

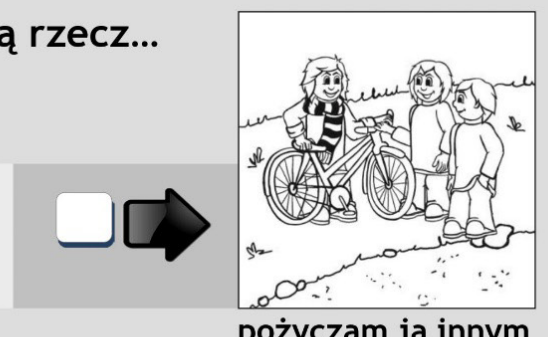

pożyczam ją innym

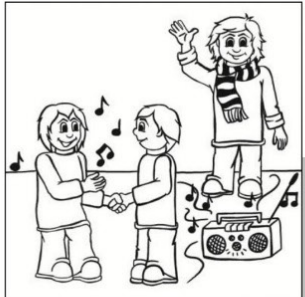

podchodzę do nich
16. Kiedy inni bawią się...

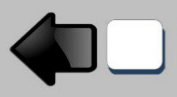

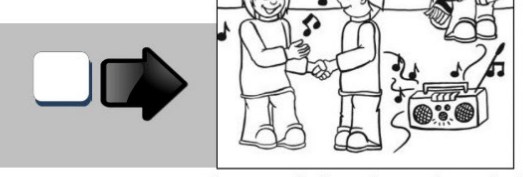

nie podchodzę do nich 


\section{A jak zachowujesz się Ty?}

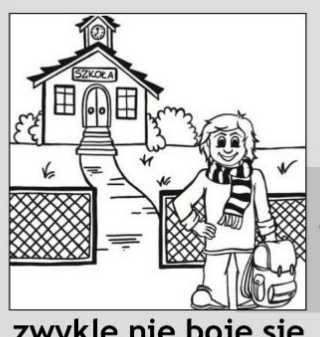

17. Kiedy idę do szkoły...

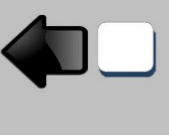

różnie
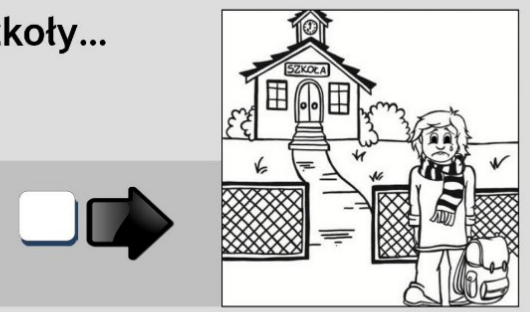

często czegoś się boję niczego

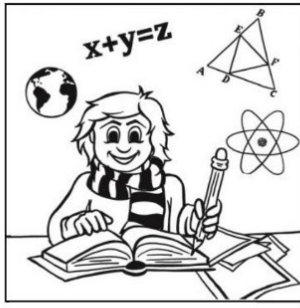

18. Nowe i ciekawe rzeczy...

lubię poznawać

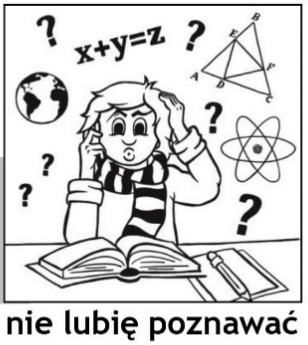

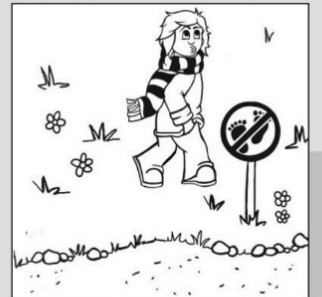

nie zwracam na nie uwagi

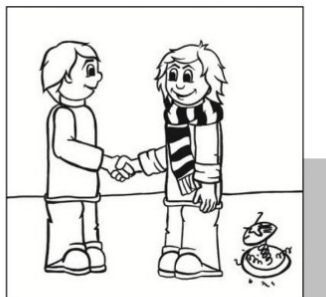

godzę się z nim szybko
19. Kiedy są jakieś zakazy...

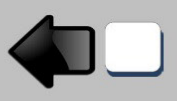

stosuję się do nich

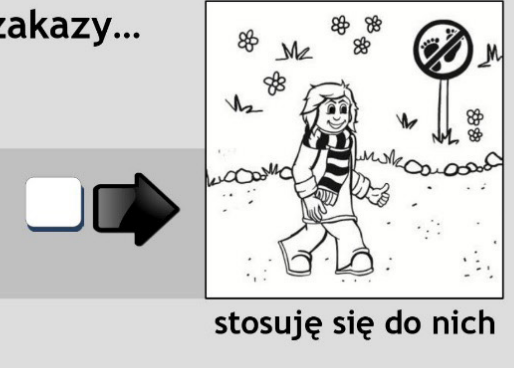

20. Kiedy ktoś mnie za coś przeprasza...

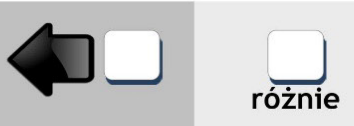

$-6-$
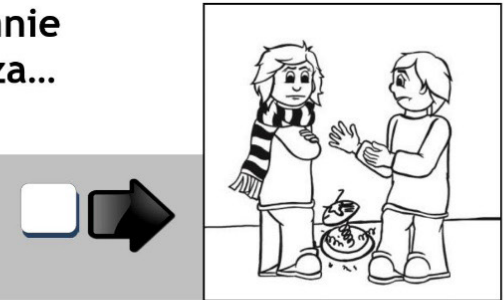

nie mam ochoty się z nim pogodzić 


\section{A jak zachowujesz się Ty?}

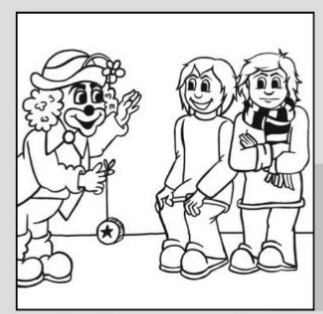

nie śmieszy mnie to aż tak bardzo

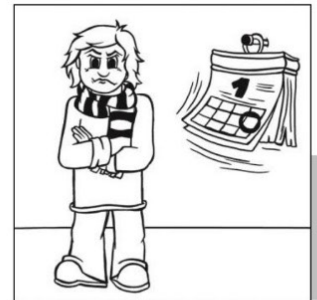

mam zły humor

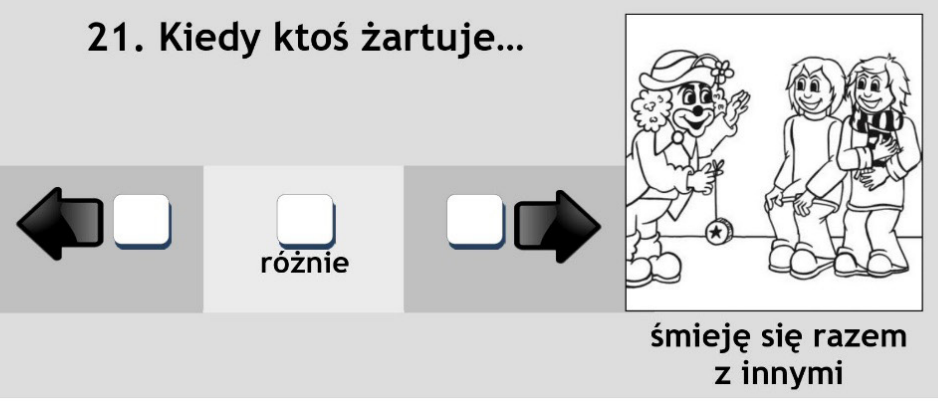

22. Zazwyczaj...

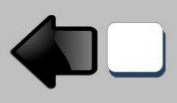

różnie
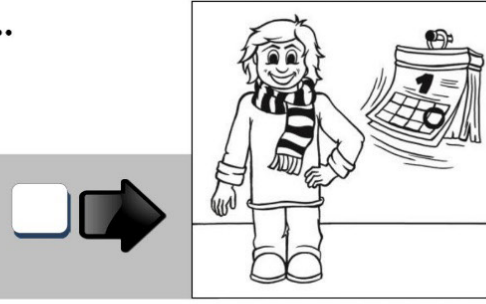

mam dobry humor

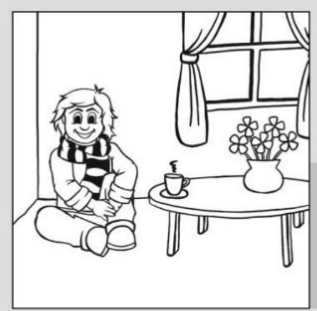

w miejscach, które dobrze znam
23. Chętniej spędzam czas...

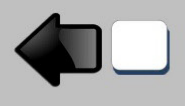

różnie

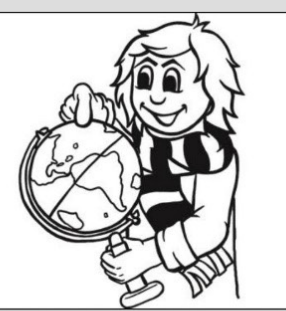

podróżując

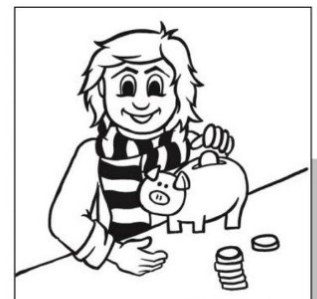

oszczędzam
24. Kiedy dostanę od kogoś pieniądze...

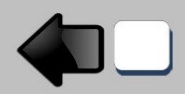

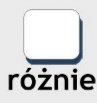

-7 -
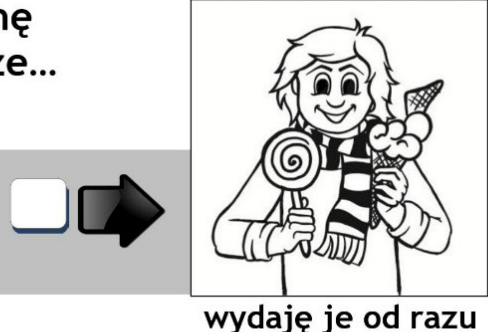

wydaję je od razu 


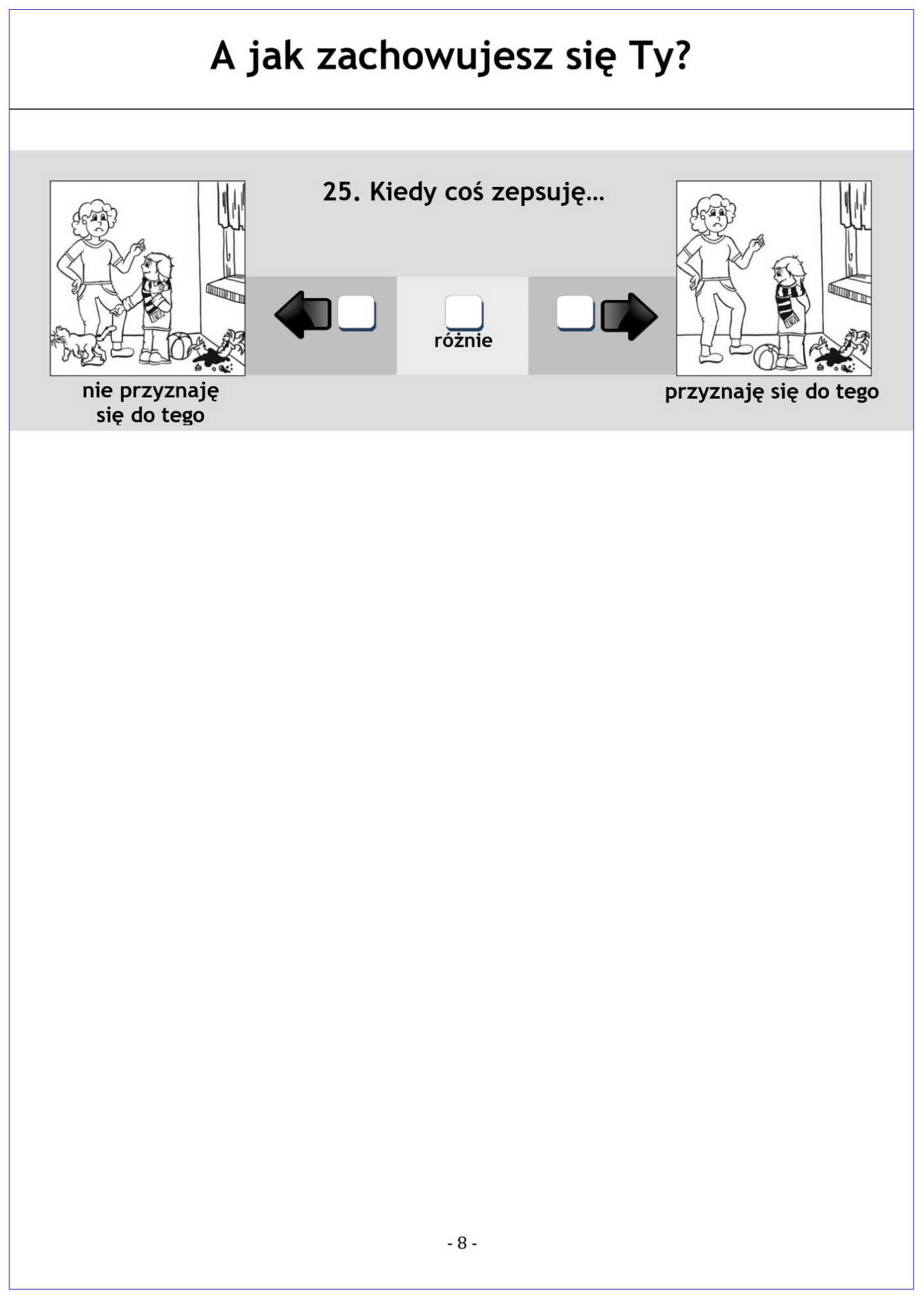




\section{ZAŁĄCZNIK 3. KLUCZ}

Sposób punktacji pozycji testowej

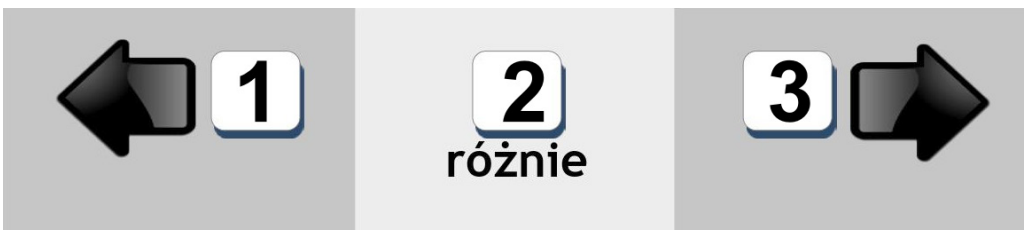

EKSTRAWERSJA: 1, 6R, 11, 16R, 21

NEUROTYCZNOŚĆ: 2R, 7, 12R, 17, 22R

OTWARTOŚĆ: 3, 8R, 13, 18R, 23

SUMIENNOŚĆ: 4R, 9, 14R, 19, 24R

UGODOWOŚĆ: 5, 10R, 15, 20R, 25

$\mathrm{R}$ - pozycja odwrotnie punktowana

\section{ZAŁĄCZNIK 4. NORMALIZACJA OPCO-D. TYMCZASOWE NORMY STENOWE}

W celu normalizacji wyników uzyskanych za pomocą kwestionariusza OPCO-D opracowano skalę stenową, która jest skalą 10-stopniową, o średniej 5,5 oraz odchyleniu standardowym równym 2 . W celu normalizacji posłużono się połączonymi próbami z badania dotyczącego oceny struktury oraz trafności $(N=863)$. W Zataczniku 3 przedstawiono sposób przeliczenia wyników surowych na steny, poniżej zaś w tabeli zaprezentowano uproszczony sposób przeliczania wyników na steny. Ze względu na fakt, że rozkłady poszczególnych skal kwestionariusza OPCO-D okazały się odbiegać od rozkładu normalnego, niemożliwe stało się ustalenie pełnego zakresu norm stenowych. Zatem kwestionariusz OPCO-D nie powinien być wykorzystywany do różnicowania wysokiego (niskiego w przypadku neurotyczności) ani przeciętnego nasilenia poszczególnych cech. Można go jednak zastosować do różnicowania niskich (wysokich w przypadku neurotyczności) i przeciętnych wyników.

Tabela 9. Normy dla skal kwestionariusza OPCO-D

\begin{tabular}{cccccc}
\hline Sten & Neurotyczność & Ekstrawersja & Otwartość & Ugodowość & Sumienność \\
\hline 1 & - & $1-1,5$ & $1-1,4$ & $1-1,3$ & $1-1,3$ \\
2 & - & $1,6-1,7$ & - & $1,4-1,7$ & $1,4-1,7$ \\
3 & - & $1,8-2,1$ & $1,5-1,7$ & $1,8-2,1$ & $1,8-2$ \\
4 & - & $2,2-2,3$ & $1,8-2,1$ & $2,2-2,4$ & $2,1-2,4$ \\
5 & $1-1,2$ & $2,4-2,5$ & $2,2-2,3$ & 2,5 & $2,5-2,6$ \\
6 & $1,3-1,5$ & $2,6-2,7$ & $2,4-2,6$ & $2,6-2,9$ & $2,7-2,9$ \\
7 & $1,6-1,8$ & $2,8-2,9$ & $2,7-2,9$ & - & - \\
8 & $1,9-2,2$ & - & - & - & - \\
9 & $2,3-2,4$ & - & - & - & - \\
10 & $2,6-3$ & 3 & 3 & 3 & 3 \\
\hline
\end{tabular}


Tymczasowe normy stenowe dla poszczególnych skal kwestionariusza OPCO-D

Tabela 10. EKSTRAWERSJA

\begin{tabular}{ccccc}
\hline Wynik surowy & $\boldsymbol{f}$ & $\boldsymbol{C f}$ & $\boldsymbol{C f}-\mathbf{1} / \boldsymbol{n}$ & Sten \\
\hline 3 & 239 & 863 & 1 & 7 \\
\hline 2,8 & 87 & 624 & 0,723059 & 6 \\
\hline 2,75 & 1 & 537 & 0,622248 & 6 \\
\hline 2,67 & 3 & 536 & 0,621089 & 6 \\
\hline 2,6 & 245 & 533 & 0,617613 & 5 \\
\hline 2,5 & 1 & 288 & 0,33372 & 5 \\
\hline 2,4 & 84 & 287 & 0,332561 & 4 \\
\hline 2,2 & 90 & 203 & 0,235226 & 3 \\
\hline 2 & 53 & 113 & 0,130939 & 3 \\
\hline 1,8 & 33 & 60 & 0,069525 & 2 \\
\hline 1,6 & 7 & 27 & 0,031286 & 1 \\
\hline 1,4 & 10 & 20 & 0,023175 & 1 \\
\hline 1,2 & 2 & 10 & 0,011587 & 1 \\
\hline 1 & 8 & 8 & 0,00927 & 1 \\
\hline
\end{tabular}

Tabela 11. NEUROTYCZNOŚĆ

\begin{tabular}{|c|c|c|c|c|}
\hline Wynik surowy & $f$ & $C f$ & $(f-1 / n$ & Sten \\
\hline 3 & 15 & 863 & 1 & 10 \\
\hline 2,8 & 1 & 848 & 0,982619 & 10 \\
\hline 2,6 & 28 & 847 & 0,98146 & 10 \\
\hline 2,4 & 16 & 819 & 0,949015 & 9 \\
\hline 2,2 & 61 & 803 & 0,930475 & 8 \\
\hline 2 & 37 & 742 & 0,859791 & 8 \\
\hline 1,8 & 89 & 705 & 0,816918 & 7 \\
\hline 1,75 & 1 & 616 & 0,713789 & 7 \\
\hline 1,6 & 65 & 615 & 0,71263 & 7 \\
\hline 1,5 & 1 & 550 & 0,637312 & 6 \\
\hline 1,42 & 142 & 549 & 0,636153 & 6 \\
\hline 1,2 & 104 & 407 & 0,471611 & 5 \\
\hline 1 & 303 & 303 & 0,351101 & 5 \\
\hline
\end{tabular}


Tabela 12. OTWARTOŚĆ

\begin{tabular}{ccclc}
\hline Wynik surowy & $\boldsymbol{f}$ & $\boldsymbol{C f}$ & $\boldsymbol{C f}-\mathbf{1} / \boldsymbol{n}$ & Sten \\
\hline 3 & 145 & 863 & 1 & 10 \\
\hline 2,8 & 51 & 718 & 0,831981 & 7 \\
\hline 2,75 & 1 & 667 & 0,772885 & 7 \\
\hline 2,6 & 179 & 666 & 0,771727 & 7 \\
\hline 2,4 & 71 & 487 & 0,564311 & 6 \\
\hline 2,2 & 164 & 416 & 0,482039 & 5 \\
\hline 2 & 53 & 252 & 0,292005 & 4 \\
\hline 1,8 & 116 & 199 & 0,230591 & 4 \\
\hline 1,6 & 16 & 83 & 0,096176 & 3 \\
\hline 1,5 & 1 & 67 & 0,077636 & 3 \\
\hline 1,4 & 49 & 66 & 0,076477 & 3 \\
\hline 1,2 & 9 & 17 & 0,019699 & 1 \\
\hline 1 & 8 & 8 & 0,00927 & 1 \\
\hline
\end{tabular}

Tabela 13. SUMIENNOŚĆ

\begin{tabular}{ccccc}
\hline Wynik surowy & $\boldsymbol{f}$ & $\boldsymbol{C f}$ & $\boldsymbol{C f}-\mathbf{1} / \boldsymbol{n}$ & Sten \\
\hline 3 & 386 & 863 & 1 & 10 \\
\hline 2,8 & 105 & 477 & 0,552723 & 5 \\
\hline 2,6 & 129 & 372 & 0,431054 & 4 \\
\hline 2,4 & 59 & 243 & 0,281576 & 4 \\
\hline 2,2 & 80 & 184 & 0,21321 & 3 \\
\hline 2 & 34 & 104 & 0,12051 & 3 \\
\hline 1,8 & 30 & 70 & 0,081112 & 2 \\
\hline 1,6 & 5 & 40 & 0,04635 & 2 \\
\hline 1,4 & 23 & 35 & 0,040556 & 1 \\
\hline 1,2 & 2 & 12 & 0,013905 & 1 \\
\hline 1 & 10 & 10 & 0,011587 & 2 \\
\hline
\end{tabular}

Tabela 14. UGODOWOŚĆ

\begin{tabular}{|c|c|c|c|c|}
\hline Wynik surowy & $f$ & $C f$ & $C f-1 / n$ & Sten \\
\hline 3 & 355 & 863 & 1 & 10 \\
\hline 2,8 & 76 & 508 & 0,588644 & 6 \\
\hline 2,6 & 163 & 432 & 0,500579 & 6 \\
\hline 2,5 & 3 & 269 & 0,311703 & 5 \\
\hline 2,4 & 57 & 266 & 0,308227 & 4 \\
\hline 2,25 & 1 & 209 & 0,242178 & 4 \\
\hline 2,2 & 79 & 208 & 0,24102 & 4 \\
\hline 2 & 31 & 129 & 0,149479 & 3 \\
\hline 1,8 & 53 & 98 & 0,113557 & 3 \\
\hline 1,6 & 15 & 45 & 0,052144 & 2 \\
\hline 1,4 & 20 & 30 & 0,034762 & 2 \\
\hline 1,2 & 5 & 10 & 0,011587 & 1 \\
\hline 1 & 5 & 5 & 0,005794 & 1 \\
\hline
\end{tabular}




\section{ZAŁĄCZNIK 5. INTERPRETACJA}

Opracowane tymczasowe normy stenowe pozwalają na interpretację wyniku przeciętnego lub wyniku niskiego (dla neurotyczności - wyniku wysokiego) uzyskanego przez osobę badaną. Należy pamiętać, że normy mają charakter orientacyjny, a uzyskany wynik może świadczyć wyłącznie o pewnej tendencji do wyróżnionych zachowań.

\section{EKSTRAWERSJA}

Wynik niski: skłonność do zachowywania dystansu w kontaktach społecznych, nieśmiałość, brak optymizmu, zmniejszona zdolność do odczuwania emocji pozytywnych, preferowanie przebywania w samotności.

\section{NEUROTYCZNOŚĆ}

Wynik wysoki: niestabilność emocjonalna, skłonność do irracjonalnych pomysłów, uczucie stresu, reagowanie lękiem, wrogością, napięciem, tendencja do zamartwiania się, uczucie wrogości, gniewu, niskie poczucie własnej wartości, zniechęcenie w trudnych sytuacjach, wstydliwość.

\section{OTWARTOŚĆ}

Wynik niski: niska twórczość i wyobraźnia, brak ciekawości i zainteresowania nowymi ideami, pomysłami, zachowawczość, preferencja tego, co dobrze znane i pożądane społecznie.

\section{SUMIENNOŚĆ}

Wynik niski: niska motywacja osiągnięć, brak wytrwałości podczas wykonywania zadania, impulsywność i spontaniczność, niska samodyscyplina, brak poczucia obowiązku, niska skłonność do utrzymywania porządku.

\section{UGODOWOŚĆ}

Wynik niski: negatywne nastawienie do innych ludzi, skłonność do oschłości i agresji $\mathrm{w}$ kontaktach $\mathrm{z}$ ludźmi, brak umiejętności współdziałania $\mathrm{z}$ innymi, tendencja do rywalizacji, niska umiejętność współczucia innym, odbieranie intencji innych ludzi jako wrogich. 